This is an Accepted Manuscript of the article Santagata, R., Viglia, S., Fiorentino, G., Liu, G., \& Ripa, M. (2019). Power generation from slaughterhouse waste materials. An Emergy Accounting assessment. Journal of Cleaner Production, 223, 536-552, available online at https://doi.org/10.1016/j.jclepro.2019.03.148 (02019. This manuscript version is made available under the CC-BY-NC-ND 4.0 license

\title{
Power generation from slaughterhouse waste materials. An Emergy Accounting assessment.
}

\author{
Remo Santagata ${ }^{1}$, Silvio Viglia ${ }^{1,2^{*}}$, Gabriella Fiorentino $^{1}$, Gengyuan $\operatorname{Liu}^{3,4}$, Maddalena Ripa $^{5^{*}}$ \\ ${ }^{(1)}$ Department of Science and Technology, Parthenope University of Naples, Italy \\ ${ }^{(2)}$ Department of Environmental Engineering Sciences, University of Florida, USA \\ (3) State Key Joint Laboratory of Environment Simulation and Pollution Control, School of \\ Environment, Beijing Normal University, Beijing 100875, China \\ (4) Beijing Engineering Research Center for Watershed Environmental Restoration \& Integrated \\ Ecological Regulation, Beijing 100875, China \\ ${ }^{(5)}$ Institute of Environmental Science and Technology (ICTA), Autonomous University of \\ Barcelona (UAB), 08193, Bellaterra, Spain
}

* Corresponding Authors:

Silvio Viglia, silvio.viglia@gmail.com; Maddalena Ripa, maddalena.ripa@uab.cat

\begin{abstract}
The linear path "extraction-production-consumption-waste", imposed by humans to natural ecosystems, where all material flows are instead circular, has become unsustainable. Understanding the potential value of some of these "by-products", in order to exploit them effectively in a biorefinery perspective, may help overcoming resource shortages and decrease environmental impacts. This study investigates energy and resource restoration from animal by-products. The slaughterhouse waste undergoes a rendering process to separate residual meal and fat. The latter is combusted in a co-generation plant to produce electricity and heat. The process is carefully assessed using Emergy Accounting approach with the aim of evaluating benefits and environmental load of the process considering the advantages achieved compared with the demand for ecosystem services and natural capital depletion. Moreover, the case aims at exploring three different methodological assumptions referring to the upstream burdens carried by the waste management system, proposing a modified exergy-based allocation rule. The electricity generated shows performances in terms of Unit Emergy Values ranging between 2.7E+05 sej/J, 2.2E+06 sej/J and 3.1E+07 sej/J among the different cases investigated, comparable to power from fossil fuels and renewables sources, and it provides an environmentally sound alternative to conventional waste disposal.
\end{abstract}

Keywords: waste management, animal by-products, resource recovery, Emergy Accounting, electricity generation, bio-refinery.

\section{Introduction}

Human pressure on the environment has reached major relevance in recent times, due to the participation of human activities contributing to the overall pollution of the planet mainly in terms of depletion of limited resources and waste generation. This is weakening the ability of ecosystems to naturally mitigate the impacts, though incentives from market and constraints from governments are influencing companies to improve their processes for the achievement of economic and environmental targets (Brown and Ulgiati, 2002; CDP, 2017; He et al., 2018). Human-dominated technological systems are not capable of recovering their inevitable produced waste flows, following the linear pattern "take-make-dispose"; conversely, in natural ecosystems, waste or by product of one process is used as an input into another process, hence materials and energy continuously loop through different processes (Gala et al., 2015). Waste generation and consequent disposal (i.e. landfilling as disposal method of about $67 \%$ of the total collected MSW worldwide according to United Nations Statistics Division, 2011) inevitably affect the environment as well as the human 
health, calling for enhanced waste management strategies. Besides, the consumption of energy at global level became twice as much between 1971 and 2001 (Talebian-Kiakalaieh et al., 2013) and it is expected to show a 48\% increase by 2040 (Wan Alwi et al., 2016). According to Global Footprint Network in 2012, the Earth's total bio-capacity (intended as the limit of the biosphere to provide support and take in waste) was 12.2 billion gha, while humanity's Ecological Footprint was 20.1 billion gha and currently humanity is taking advantage of world's stocks of natural assets generated in earlier times (Odum, 1973; WWF, 2016). The direct and indirect demand of resources (i.e. oil, chemicals, minerals, treatment of human residues) is depleting natural capital storage (Agostinho et al., 2013). In this respect, material circularity is a crucial area in the search for alternatives for fossil based raw material and energy. Circularity implies increasing energy efficiency and reducing fuel consumption and resource depletion, achieving also a decrease of greenhouse gases (GHG) emissions for energy generation, mobility and heating (Giampietro et al., 2012; Martire et al., 2017). Then, consumption-oriented concerns and energy planning should better support climate policies. Achieving better efficiency in a sustainable development perspective should include a better efficiency, in an ecological perspective, in the handling of waste (Corcelli et al., 2017; DíazVillavicencio et al., 2017). Sustainable development is assessed also through the lens of ecoefficiency, as analytical and quantitative approach, with the aim of maintaining and improving the value of products, while reducing resource consumption (Caiado et al., 2017). Since the largest contribution to GHG emissions comes from the energy sector, it becomes crucial to implement emissions reduction strategies from this sector (Eurostat, 2012; Evangelisti et al., 2015). Lignocellulosic residues, exhaust, cooking oil and animal waste proved to have potential to be converted into biodiesel for fossil fuel replacement and decreased GHG emissions The results have shown that a large variability is associated with the nature of the oil used for biodiesel production (Chen et al., 2018; Jørgensen et al., 2012). In this context animal fat waste (AFW) have gained great interest as profitable alternative to vegetable oils for biodiesel making (Adewale et al., 2015; Alptekin et al., 2015; Behçet et al., 2015; Chakraborty et al., 2014) or for direct combustion in power plants. Animal fat waste is a relevant side product of the meat processing industry for human consumption. 2002/1774/EC defines animal by-products as the fraction of animals and animal products not destined to human nutrition. An enormous generation of organic waste is thus caused by food, drug, cosmetic and leather industries, among others, potentially source of dangerous pathogens (Devaraj et al., 2018). Almost $50 \%$ of livestock becomes by-products, which still keep a useful fraction of energy available (animal fat: $3.98 \mathrm{E}+04 \mathrm{~J} / \mathrm{g}$ average, animal meal: 1.85E+04 J/g average) (Ariyaratne et al., 2010; Haines, 2004; Kumar et al., 2006). Jayathilakan et al. (2012) show how a great variety of products and commodities can be obtained from the proper management, through different processes, of animal waste and by-products (i.e. chemicals and pharmaceuticals from blood and gelatine, clothing from hides and skin, etc.), in a bio-refinery perspective. A conventional refinery yields several petrol-based fuel and products while a bio-refinery produces fuels, power, heat and value-added chemicals from using as resource residual biomass from agriculture, forests or industries (Forster-Carneiro et al., 2013). Bio-refinery implementation should plan also a dynamic, growing network of already existing systems, avoiding the creation of brand new complexes (Hagman et al., 2017).

The present paper explores, by means of the Emergy Accounting approach (hereafter EMA, see Materials and Methods section below for further details), the environmental performances of the production of animal meal and fat from slaughterhouse waste, and of the subsequent production of electric energy from processed animal fat, in order to comply with European waste directive (EC, 2008) and with the new Renewables, Energy Efficiency and Governance legislation as established on 24 December 2018 (EC, 2018a, 2018b, 2018c). The proposed study complements, through the specific environmental quality focus of the emergy approach, a previous investigation of the same process carried out by means of Life Cycle Assessment (LCA) method (Santagata et al., 2017). The process, consisting of a rendering phase and an electricity generation phase, has been analyzed under different emergy algebra perspectives (allocation according to splits and co-products features, see below), in order to understand how assumptions on output flows affect the results. Moreover, considering a different definition of co-products and by-products, a modified allocation scenario is 
proposed after Brown (2015), where the total input emergy is assigned to the animal by-products according to their residual work potential (exergy) and related role in the downstream production processes. The range of environmental performance indicators of the electricity, calculated under these different assumptions, has been compared to the emergy indicators of the Italian average electricity mix as well as to those of electricity obtained by only using fossil fuels or photovoltaic (Brown et al., 2012). Further comparison with EMA applied to municipal waste disposal via landfill and incinerator (Cherubini et al., 2008) has been performed. Beyond the novelty of the case-study, the main goal of the present work is to explore different methodological options (electricity production versus waste disposal) implied by different assumptions and burden choices, which affect the results. Materials, when their potentials are used, disperse spatially to concentrate once again in a distinct time and place. It is really important for humanity, then, to adjust its production and consumption patterns to the natural cycling material loops (Brown and Buranakarn, 2003). In particular, waste management systems are really complex, thus requiring a peculiar attention when dealing with assumption and methodological choices (Gala et al., 2015). The present study shows how, being the waste on the verge between consumption and production (via recycling), the results are very sensitive to the framework applied for assessment. Moreover, the amount of resourcegenerating environmental work needed per unit of product or service delivered by a process, calculated through EMA, can be interpreted as a new and more comprehensive measure of ecoefficiency.

\section{Materials and Methods}

The presented work used EMA as methodological framework. Emergy is defined as the energy (of one kind) used in a system for transformations (Brown and Ulgiati, 2004a; Odum, 1996). In EMA, the boundaries are established at biosphere level. In so doing, the whole supply chain (resource generation, processing and disposal), is taken into account, together with the environmental contribution for the generation of storages and flows of natural resources (renewable and nonrenewable), flowing through the network directly and indirectly supporting the analyzed system.

\subsection{Case study description}

The process presented is based in Campania region (Italy) and managed by a company named Proteg S.P.A. This electricity generation process, delineated in Figure 1, uses animal by-products, to be processed, in order to obtain purified fat used as fuel for electric energy cogeneration of about 5.1 MW. A detailed explanation of the process can be found in Santagata et al., 2017. 


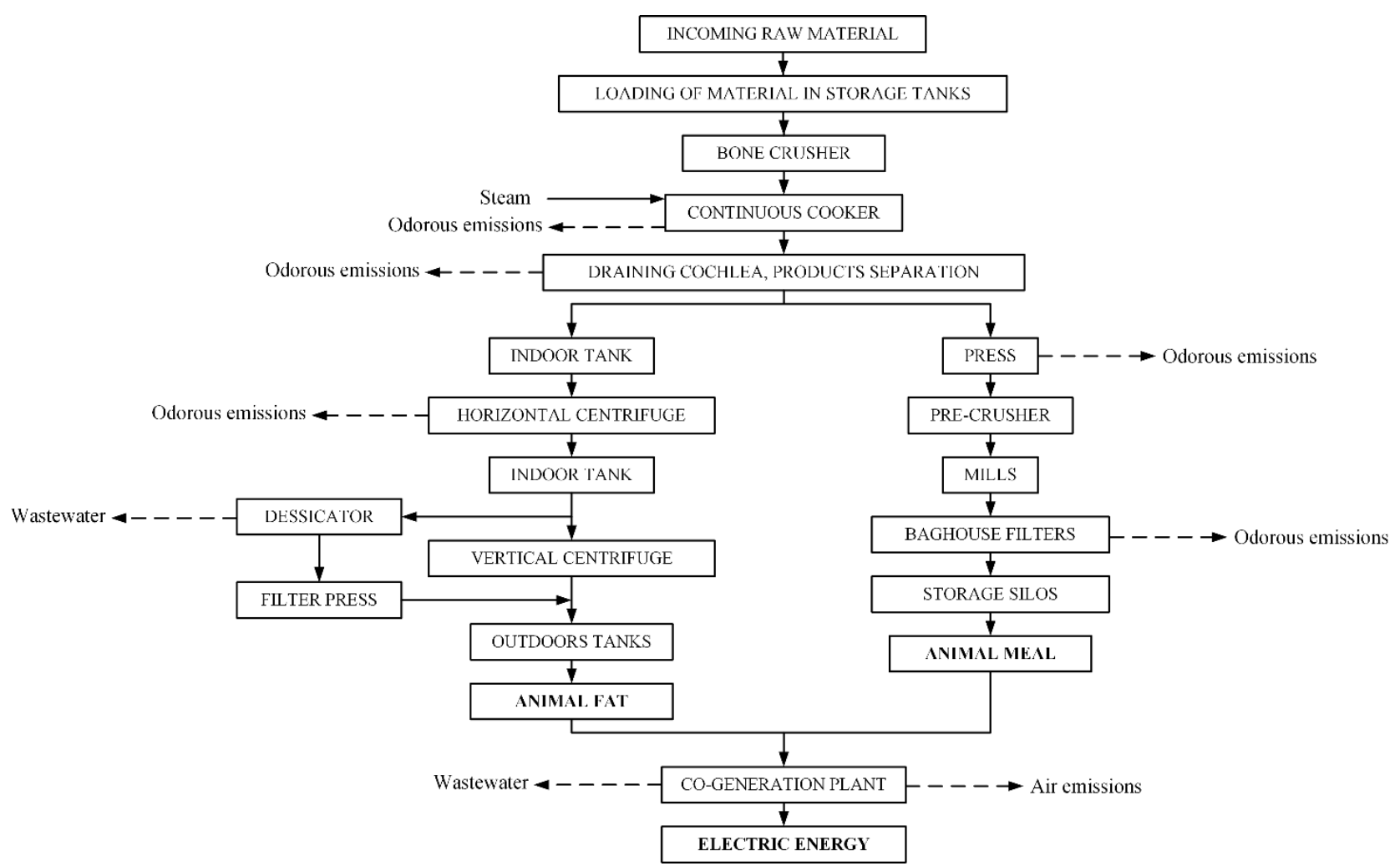

Figure 1 - Flow chart of rendering and power generation processes (Santagata et al., 2017).

\subsection{Emergy Accounting}

EMA assesses the ecosystem support to a process. Specifically, EMA allows to take into account quality differences among different kinds of resources and energy, based on the work done by the biosphere to generate them (Brown and Buranakarn, 2003; Odum, 1996), also including humandominated processes as an integral part of biosphere.

EMA is a supply-side oriented method, since it accounts for direct and indirect contribution to systems, considering also contributions from labor and services. In fact, assessing an investment also means quantifying the unavoidable cost for a resource replacement (Spagnolo et al., 2018).

The emergy unit is the solar emjoule (sej), defined as the cumulative amount of available energy (with reference to the solar kind) converging to create a resource, a product or a service. Solar energy is doubtless the greatest source available for Earth's processes, thus it is reasonably used as the reference type of energy. Resource generation virtually embodies the available energy flows invested over time within the biosphere processes, taking into account both the evolutionary "trial and error" patterns as well as the different quality of input flows (geothermal, solar, gravitational), each quantified in terms of its equivalency to the solar radiation flow. The "em-joule" term instead of just "joule" suggests much more in terms of biosphere dynamics than just the heat content expressed by a plain energy joule. Therefore, the total emergy (U, Equation 1) driving a process is used to quantify the total "environmental production cost" of products, by summing up all the inflows converging into the process itself (Brown et al., 2016; Campbell, 2016). Based on the total emergy U and the process yield (Y), the emergy investment per unit output can also be calculated (Unit Emergy Value, UEV, generally expressed as sej/J or sej/g, Equation 2).

$$
\mathrm{U}=\Sigma \mathrm{f}_{\mathrm{i}} * \mathrm{UEV}_{\mathrm{i}} \quad \mathrm{i}=1, \ldots, \mathrm{n}
$$

where $\mathrm{U}$ represents total emergy, $\mathrm{f}_{\mathrm{i}}$ is the $\mathrm{i}$-th inflow of energy or matter, UEV is the Unit Emergy Value of the $\mathrm{i}$-th inflow, $\mathrm{n}$ is the number of supporting inflows.

$$
\mathrm{UEV}=\mathrm{U} / \mathrm{Y}
$$


where $\mathrm{Y}$ is a process yield (output) expressed as joule, gram, or other appropriate units. If the yield $\mathrm{Y}$ is measured in joule, as it is the case with many energy flows, then the UEV is called "transformity", defined as sej/J. The transformity of solar radiation is by definition set equal to $1 \mathrm{sej} / \mathrm{J}$.

All emergy values, including UEVs, are calculated with reference to a Global Emergy Baseline (GEB), i.e. the total emergy that is available annually to all the processes occurring within the biosphere. In this paper all the UEVs are related to the GEB calculated by Brown et al. (2016), i.e. $12.0 \mathrm{E}+24 \mathrm{seJ} / \mathrm{yr}^{1}$ (all UEVs calculated according to different baselines were converted by multiplying them by the ratio between the $\mathrm{GEB}_{2016}$ and the relative older baseline). Additional information about EMA can be found in Appendix A.

The indices calculated in this study are the Emergy Yield Ratio (EYR), the Environmental Loading Ratio (ELR), the Environmental Sustainability Index (ESI) and the percentage of renewability (\%Ren). The definitions of these indices can also be found in Appendix A.

\subsection{Comparison between LCA and EMA}

The assessment of efficiency and environmental performances of systems is still an essential point for the development of more feasible production and consumption patterns. The criteria for comparison of systems providing analogous services, is comparing the resources demand per unit of output. To ensure reliability of such comparisons, and to overcome the incongruences still present in many published studies, a shared assessment standardization should be adopted (Brown et al., 2012). LCA and EMA show some common ground in the way they are performed, mainly regarding the inventory phase and the results understanding, but they also show non-negligible differences, LCA looks at the process boundaries from cradle to grave with focus on (renewable and nonrenewable) resource use under human control. On the other hand, EMA, although focusing on the local system, expands its focus over the biosphere space and time scales, also accounting for the time embodied in resource generation, the free ecosystem services, the evolutionary pathways over the resource supply chain, the societal aspects embodied in Labor and Services (L\&S) applied. Since the emergy has been considered as an additional upstream cost and impact within a Life Cycle Impact Assessment (LCIA), some researchers are trying to merge EMA into LCA pieces of software and are pushing for increased standardization of the method, in order to make it more easily usable taking advantage of existing LCA libraries (Ingwersen, 2011; Kursun et al., 2015; Marvuglia et al., 2013; Nimmanterdwong et al., 2018; Raugei et al., 2014, 2007; Reza et al., 2014; Rugani and Benetto, 2012; Wang et al., 2017). The significant difference between LCA and EMA is the definition of system boundaries, that is strictly connected to the perspective used to analyze a given system: while in LCA the boundaries generally are the temporal and spatial ones of the life cycle of a given process, in EMA the system is considered as a part of a greater natural system, including all direct and indirect flows needed, on a larger spatial and temporal frame, as shown in Figure 2.

\footnotetext{
${ }^{1}$ The unit sej is always written without capital $\mathrm{J}$, being a shortening for solar emjoule. Only when it is used in reference to the GEB, the unit is written as seJ, with capital $\mathrm{J}$. This is because the baseline amount still is the sum of available energy flows (solar, gravitational, geothermal, measured as joule), all converted to solar units on the basis of their thermodynamic characteristics (De Vilbiss et al., 2016). Instead, when the GEB is used as the reference for calculation of UEVs over biosphere processes, other aspects are included (time, evolution, convergence) which requires a different unit to prevent misunderstandings (emjoule).
} 


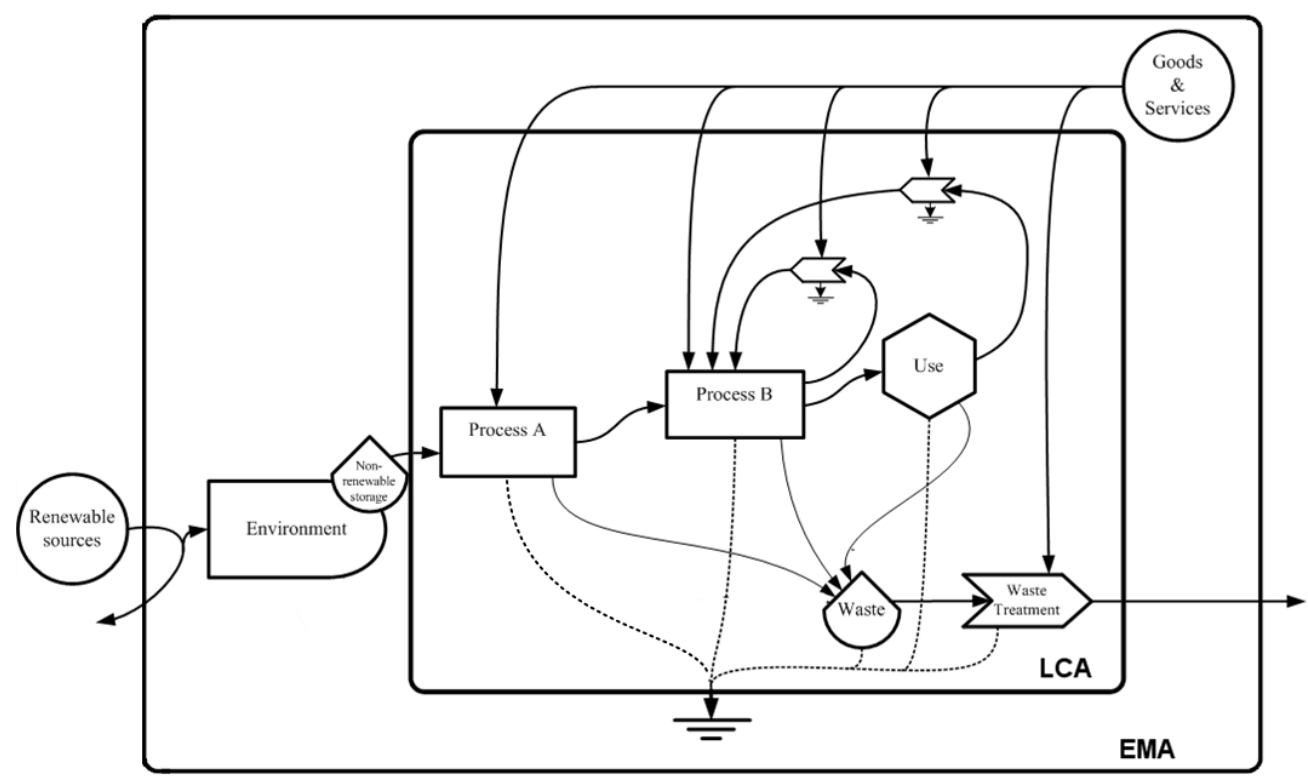

Key for symbols (Odum, 1996)

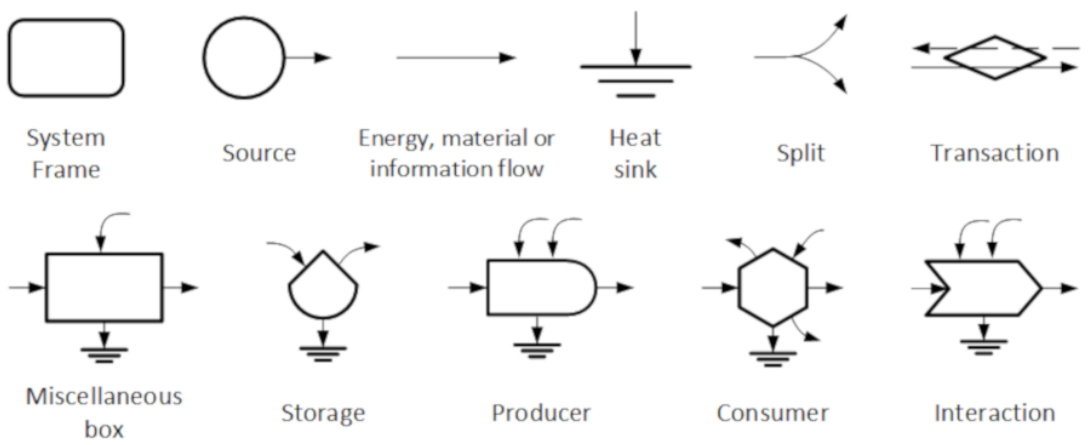

Figure 2 - Different scale of interest in Life Cycle Assessment and Emergy Accounting (Ripa, 2014).

It is clear that the LCA has a 'consumer-side' perspective, while EMA has an ecological 'donor-side' perspective (Gala et al., 2015; Raugei et al., 2014; Viglia et al., 2013). LCA provides useful information about the resource and environmental cost of a given product and/or process but it only accounts for matter and energy flows occurring under human control. Typically, LCA does not accounts for flows outside of market dynamics (such as environmental services) and flows that are not associated to significant matter and energy carriers (such as labor, culture, information), and the quality and renewability of resources, in terms of biosphere activity generation processes and times are not generally taken into account in LCA evaluations (Ulgiati et al., 2006). Ecosystem services (ES) are gaining increased attention with respect to the interaction between human activities and the capacity of lands to deliver services (Rugani et al., 2018). Recent works try to incorporate the ES dimension within the LCA method, i.e. considering their loss as a potential damage (Pavan and Ometto, 2018) or including ecological components and accounting for regional variation (Liu et al., 2018a, 2018b), yet raising the need for appropriate and standardized data to be included in LCA databases and methods for accounting. Emergy attempts to measure the environmental work required to generate (ecosystem) goods and services that can be used by humans. Similarly, fossil fuels, which were slowly formed through geological processes that cumulatively required huge amounts of exergy, are reasonably labeled by EMA as more 'valuable' than most contemporary biomass-derived fuels, which can potentially be replaced overmuch shorter time scales. The main different aspects between LCA and EMA are summarized in Figure 3. 


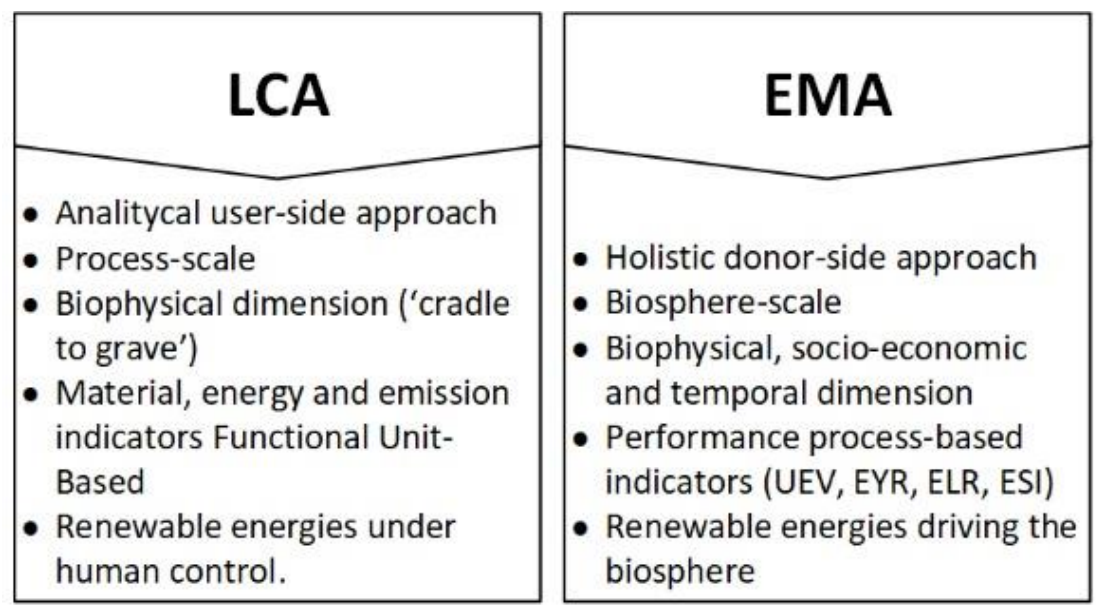

Figure 3 - Different characteristics of LCA and EMA (Ripa, 2014).

\subsection{Definition of system boundaries}

The largest share of waste in meat business is at the butchery level (Jayathilakan et al., 2012). This kind of by-products are defined as the fraction of animal not destined to human nourishment (i.e. bones, tendons, skin, the contents of the gastro-intestinal tract, blood and internal organs). About half of the live animal becomes by-products that is not destined to human nutrition. Doing so, an important stock of potential benefit is lost, while the costs for disposal increase. Animal by-products could be used for countless application, the first of which is edible products, after adequate treatments (i.e. sausages from blood or lard from the treatment of gelatin extracted from animal skin); blood can be treated to have therapeutic components and many blood components can be separated for chemical and medical uses; hides and skins can be used for clothing, for cosmetic products and glues; gelatin and collagen have food, medicinal and pharmaceutical applications; meat and bone meal is used in animal nutrition and as fertilizer; manure can be anaerobically digested to produce methane; animal fat can be treated in different ways to produce bio-fuels (Jayathilakan et al., 2012).

Such a 'bio-refinery', capable of exploit all reusable fractions of animal waste to provide products, could be able to connect the production step (mainly rural) and the consumption step (mainly urban). Considering the boundaries of the entire rural/urban process, the situation would be the one shown in Figure 4 , in which there is a stream of materials from the farm to the slaughterhouse, the latter providing meat to the urban consumers and waste to the bio-refinery; the bio-refinery uses waste to produce commodities (i.e. cosmetics, electricity, bio-fuels, etc.). The entire process is powered by renewable and non-renewable input flows from the external system. Bio-refineries, like conventional oil refineries, show an optimal multifunctional capability (Cherubini et al., 2011). 


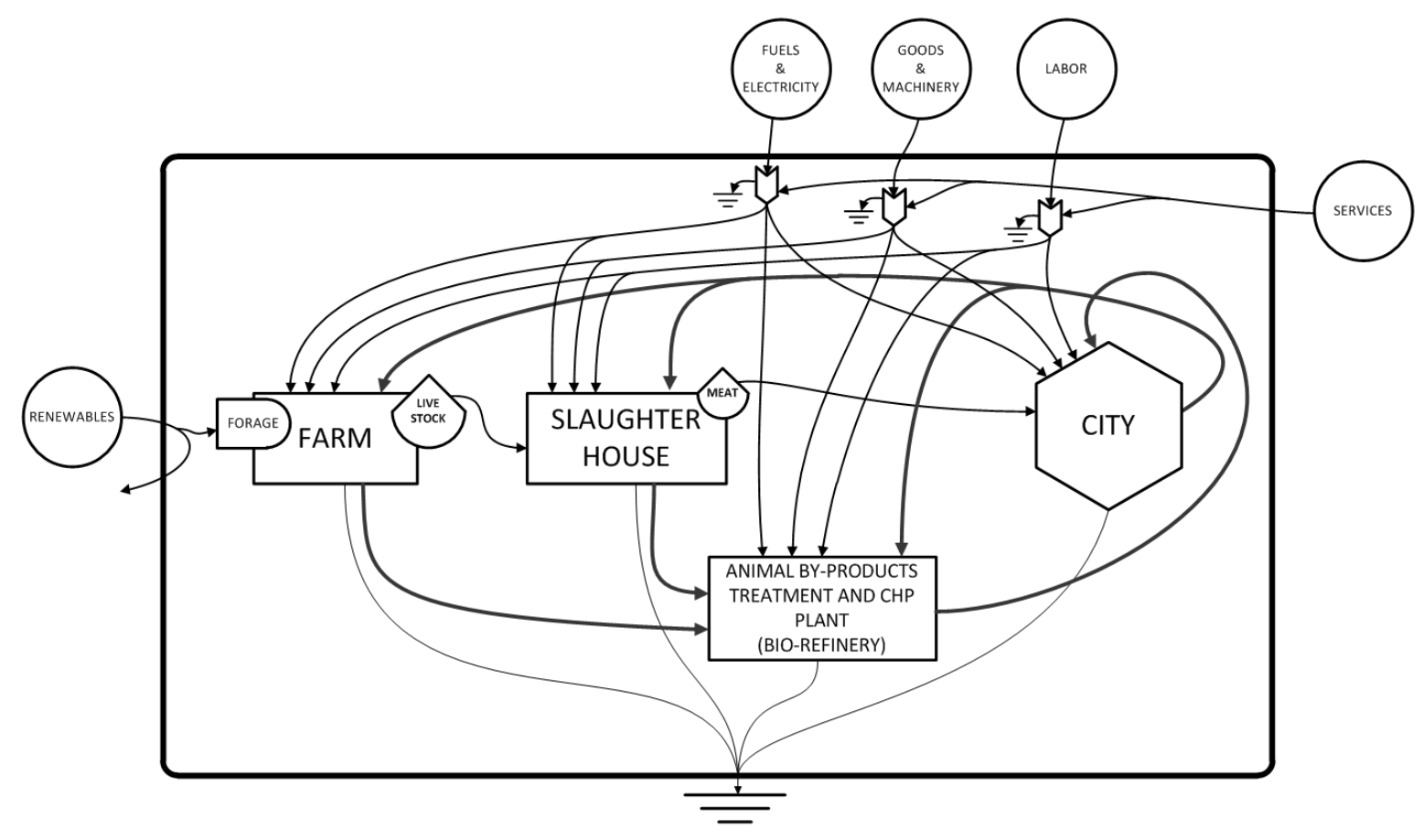

Figure 4 -Diagram showing the bio-refinery as link between the rural and urban phases.

Indicators are largely affected by assumptions made during the accounting procedures (i.e. chosen boundaries, categorization of input flows). Making a distinction among local and imported investments could be significant when comparing imported resources with resources extracted and/or produced within an economy, giving information about autonomy and self-sufficiency. However, this distinction is not useful when assessing individual processes, where, in extreme cases, all inputs would be considered as imported. (Brown et al., 2012).

In this paper, boundaries have been drawn around the process, including slaughterhouse producing meat and animal by-products, indicated in the upper left corner of the diagram in Figure 6.

\subsection{Assumptions made about split, coproduct and by-product flows}

In order to combine LCA and EMA, different assumptions about the animal by-products entering the process have been made. Keeping in mind the emergy algebra rules (Odum, 1996), different cases can be identified, depending on the emergy algebra choices about input, intermediate and output flows (as splits, co-products and by-products).

The process investigated in this study has a twofold aim: (i) getting rid of a dangerous waste (sink point of view) and (ii) converting it to energy (source point of view).

The problem of how to account for by-products has been widely discussed in LCA studies. LCA often adopts the so-called "zero burden approach", meaning that, when a waste management application is investigated, the waste flows enter the process carrying no burdens, in order to permit a comparative analysis between different waste treatment systems (Finnveden, 1999). Co-production, according to the standardized procedures (CEN, 2006a, 2006b; JRC, 2010), is dealt with through different kinds of allocation or system expansion, so "by-products" could be considered as waste or co-product basing on the investigated system. For agricultural systems, the economical allocation is often used, but recently a wide number of "biophysical" allocation methods have been proposed (Mackenzie et al., 2017). The issue has not received the same level of attention within the EMA scientific community. The issue deals strictly with the peculiar characteristics of emergy algebra discussed in Appendix A. Valuable inputs recently came from Brown (2015) and from Gala et al. (2015). The former, starting from H.T. Odum's idea that when a material is dispersed or recycled, its emergy decreases and it cannot be double counted in feedbacks, suggests that by-products should not be accounted for but, 
instead, they should be burdened with only a fraction of the total emergy, in proportion to their mass (in some way considering them as a split of the main output). This revised algebra rule suggests that undesired output flows (such as, for example, atmospheric emissions of $\mathrm{CO}_{2}$ ), when unable to further drive further downstream processes, should be considered as waste flows, not product flows, and therefore should not be assigned the total emergy driving the system, but only a smaller fraction proportional to their residual ability to drive a downstream process. However, allocation proportional to the mass, as suggested by (Brown, 2015) bears the risk that by-products generated in large amounts but hardly able to drive any significant downstream process (for example, the $\mathrm{CO}_{2}$ emissions from combustion or a process wastewater) are credited a large fraction of the driving emergy, no matter their real contribution to the next steps of the system's dynamics. Gala et al. (2015) confirm the importance of merging the LCA and emergy methods, pointing out that what has been done in LCA could be the starting point to develop a similar framework in EMA. According to EMA algebra, waste should be considered as co-products or split. Wang et al. (2017) claim that, in order to achieve a higher comprehension in recycling processes, evaluating the internal dynamics of the system could be relevant for EMA applications, and propose a set of modified indicators.

In this work, a modified allocation rule is presented, using the exergy content proportion of the byproducts, where a low exergy content indicates the by-product to be close to the equilibrium with the surrounding environment (heat sink) and therefore no longer considerable a product at the scale of the investigated system. Such a choice would not prevent the possibility that a very reactive byproduct (i.e. a toxin, characterized by relatively high chemical activity and exergy) might be assigned a significant fraction of the total input emergy although showing a very small mass, thus translating into a relatively high UEV. Vice versa, a large number of low-exergy by-products (i.e.: inert materials) would be assigned a low emergy input, translating into a lower UEV.

The full derivation of the exergy content of a material flow is explained in Szargut's article on "Chemical Exergies of the Elements" (Szargut 1989). Calculations' details can be found in the Appendix A.

The different methodological choices are explored in the following cases:

- Case 1 (Figure 5 - a): Split with economic allocation: the driving emergy is allocated according to the economic value of the output flows. In the case of a slaughterhouse process, only the main products (i.e. meat and leather) have a recognized market value, while byproducts are generally considered having zero economic value and disposed of as waste. Therefore, an emergy equal to zero is assigned to the animal by-products entering the power plant. This approach is in line with the emergy algebra rules about feedback flows as well as with the usual LCA methodological approach, named 'zero burden', generally applied when dealing with waste streams entering a recycling process (Finnveden, 1999).

- Case 2 (Figure 5-b): co-products. Animal by-products and meat flows are considered as coproducts of the slaughtering process (meat cannot be obtained without producing also byproducts), so the total emergy of the process is assigned to both of them.

- Case 3 (Figure $5-\mathrm{c}$ ): split with exergy based allocation to the by-product.

Finally, once the emergy of the by-product, $\mathrm{U}_{\text {by-product, }}$ is calculated, its UEV can be computed according to Eq. (2). 


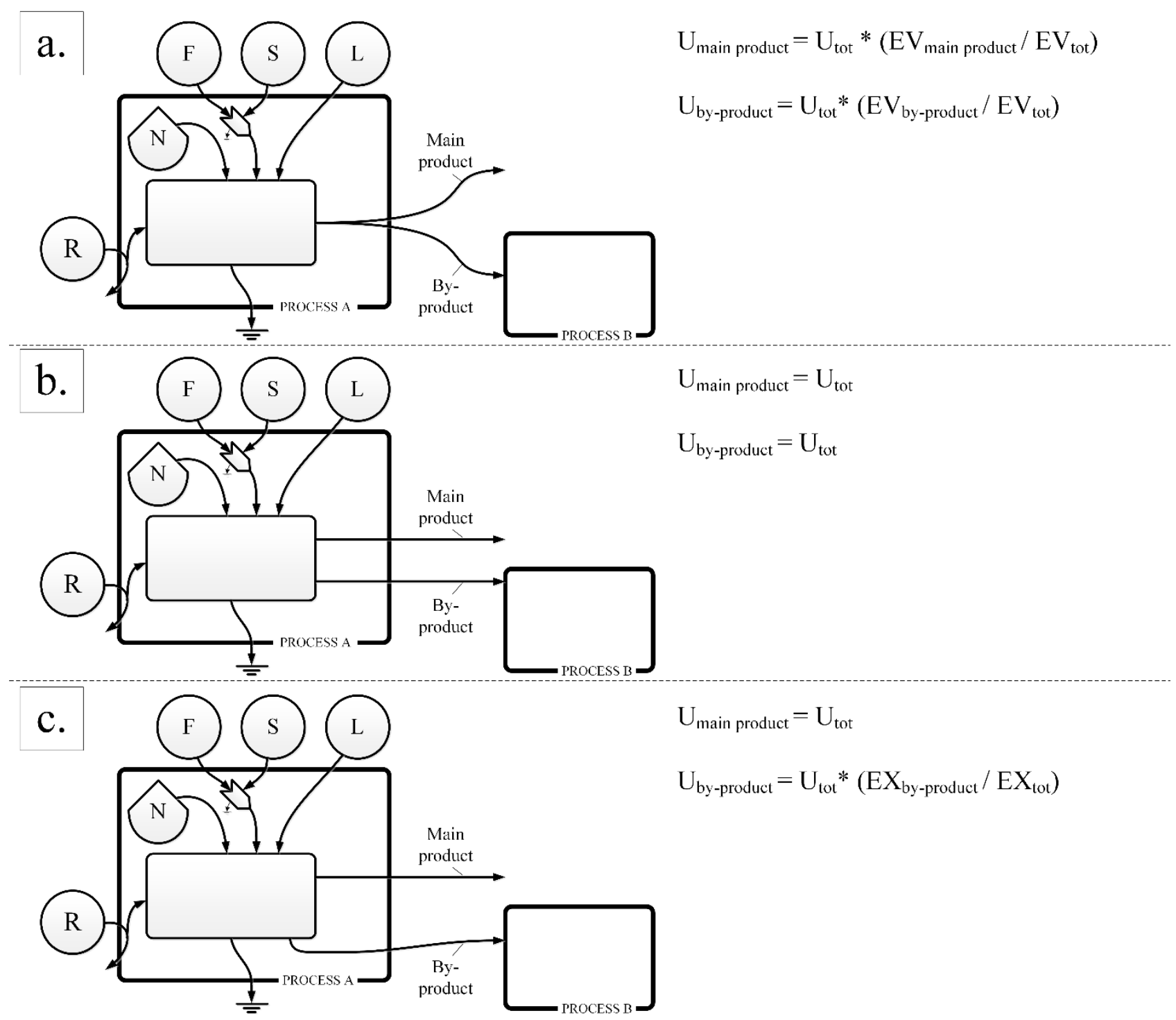

Figure 5 - Different perspectives regarding the allocation choices between meat and animal byproducts among Case 1 (where economic value of the by-product is placed equal to zero), Case 2 and Case 3 (EV: Economic value; EX: exergy content).

It should be pointed out that the choice of considering "co-products" or splits some of the flows in our process is an extreme expression of the market distinction between products that are economically valuable to humans and products having very low market value. This is a typical "grey area" case of difficult distinction between splits and co-products, where scale and human preferences affect the judgment. Nevertheless, this anthropocentric perspective in approaching the "by-products" is not suitable when dealing with natural systems, in which organisms would not make such a distinction. Bacteria would not make any difference between meat and by-products, since there is no difference between things that could or could not be sold to humans basing only on what is more desirable to them. However, in so doing we are able to generate a lower and upper performance bound for the intended product, for more appropriate comparison with alternatives.

\section{Results}

The diagram in Figure 6 describes input flows, components, feedback loops and product flows in the Case 1 scenario. Table 1 summarizes all the relevant input and output flows of the rendering and the electricity generation processes from CASE 1 (the Table relative to CASE 2 is shown in Appendix B). Considering that a fraction of the electricity generated is fed back to upstream steps of the process 
itself, the output flow of electricity in Table 1 is net production.

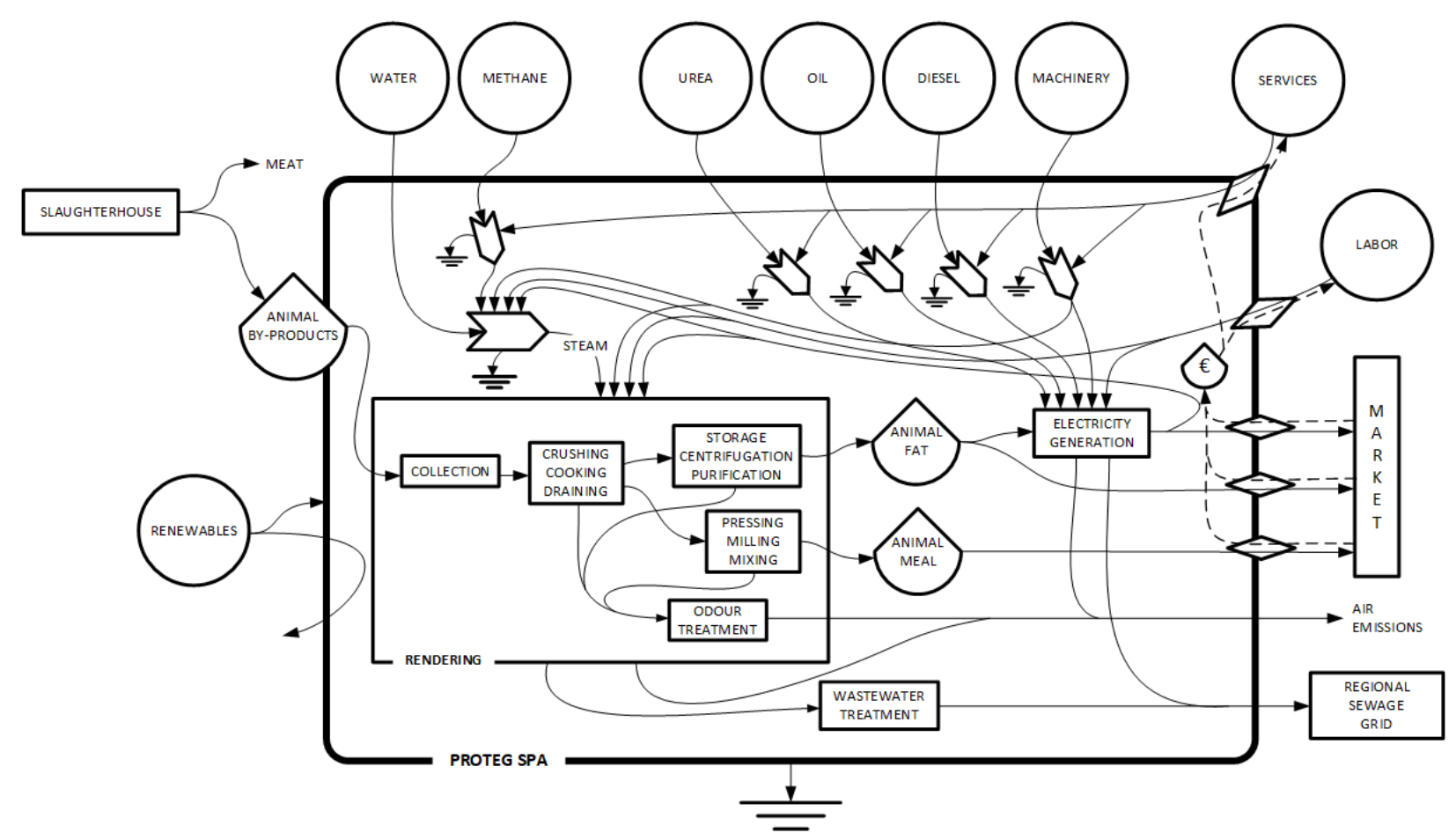

Figure 6 - System diagram of CASE 1 (where the flow from slaughterhouse is considered a split)

All data used for the inventory phase come from the investigated company, literature and/or specialized archives or websites (i.e. the data regarding solar radiation, wind, the overall quantity of rain in the timespan considered, etc.). All raw energy and material flows have been proportioned to the selected functional unit of $1 \mathrm{MWh}$ of electric energy produced (data references and calculation procedures can be found in Appendix A). According to the emergy algebra and calculation procedures explained in Brown and Ulgiati (2016), $\mathrm{R}$ is calculated in Table 1 as the largest among the sum of the primary sources (solar, geothermal and gravitational, $2.04 \mathrm{E}+09 \mathrm{sej} / \mathrm{yr}$ ) and the secondary and tertiary sources (rain, wind, etc). $\mathrm{R}$ is then added to $\mathrm{N}$ and $\mathrm{F}$ to account for the raw emergy supporting the system. L\&S (a measure of inflows related to information, know-how and large scale infrastructure) are then added to yield the total emergy U. The item 6 (animal by-products from slaughterhouse, entering the electricity production process) is assigned a UEV equal to zero, which translates in a zero emergy flow, according to the 'zero burden' approach (Case 1). Instead, in Table B.1 and Table B.2 (Appendix B), the same item is assigned respectively the entire emergy calculated in the livestock phase (Case 2) and a percentage of this emergy proportional to the output exergy fraction of byproducts (Case 3$)$.

Table 1 - Electricity from animal by-products (Case 1)

\begin{tabular}{|c|c|c|c|c|c|c|}
\hline \# & Item & Unit & Inputs & $\begin{array}{c}\text { UEV } \\
\text { (sej/unit) }\end{array}$ & $\begin{array}{c}\text { Emergy } \\
\text { (sej/MWh) }\end{array}$ & Ref. \\
\hline \multicolumn{7}{|c|}{$\begin{array}{c}\boldsymbol{R}-\text { Renewable Inputs Locally Available } \\
\text { Primary renewable sources }\end{array}$} \\
\hline 1 & Sun & $\mathbf{J}$ & $1.4 \mathrm{E}+08$ & $1.0 \mathrm{E}+00$ & $1.4 \mathrm{E}+08$ & Def. \\
\hline \multirow[t]{2}{*}{2} & Deep Heat & $\mathrm{J}$ & $3.9 \mathrm{E}+05$ & $4.9 \mathrm{E}+03$ & $1.9 \mathrm{E}+09$ & [1] \\
\hline & Secondary & irces & & & & \\
\hline 3 & Rain & $\mathrm{J}$ & $1.2 \mathrm{E}+06$ & $7.0 \mathrm{E}+03$ & $8.7 \mathrm{E}+09$ & [1] \\
\hline 4 & Wind & $\mathbf{J}$ & $4.0 \mathrm{E}+06$ & $8.0 \mathrm{E}+02$ & $3.2 \mathrm{E}+09$ & [1] \\
\hline
\end{tabular}




\section{N - Non-renewable Inputs Locally Available}

5 Underground water

$\mathrm{J}$

F - Non-renewable Imported Inputs

$\begin{array}{cll}6 & \text { Cat. 3 Material (d.m.) } \\ 7 & \text { Natural Gas } \\ 8 & \text { Diesel for transportation } \\ 9 & \text { Diesel for engine } \\ 10 & \text { Lubricating oil } \\ 11 & \text { Urea } & \text { J } \\ & \text { Machinery }\end{array}$

12

\section{Machinery}

L\&S - Information and Infrastructure

\begin{tabular}{llccccc}
28 & Labour & $\mathrm{ppl} / \mathrm{yr}$ & $1.4 \mathrm{E}-03$ & $4.4 \mathrm{E}+16$ & $6.0 \mathrm{E}+13$ & {$[13]$} \\
29 & Services & $€$ & $7.4+01$ & $1.7 \mathrm{E}+12$ & $1.2 \mathrm{E}+14$ & {$[13]$} \\
\hline \multirow{2}{*}{30} & Eutput & & & & & \\
& & $\mathrm{MWh}$ & $8.6 \mathrm{E}-01$ & $1.2 \mathrm{E}+15$ & $1.0 \mathrm{E}+15$ & {$[14]$} \\
31 & Electricity (without L\&S) & $\mathrm{MWh}$ & $8.6 \mathrm{E}-01$ & $9.7 \mathrm{E}+14$ & $8.3 \mathrm{E}+14$ & {$[14]$} \\
& & $\mathrm{J}$ & $3.1 \mathrm{E}+09$ & $2.7 \mathrm{E}+05$ & $8.3 \mathrm{E}+14$ & {$[14]$} \\
32 & Animal Fat (with L\&S) & $\mathrm{g}$ & $2.0 \mathrm{E}+05$ & $5.1 \mathrm{E}+09$ & $1.0 \mathrm{E}+15$ & {$[14]$} \\
33 & Animal Fat (without L\&S) & $\mathrm{g}$ & $2.0 \mathrm{E}+05$ & $4.1 \mathrm{E}+09$ & $8.3 \mathrm{E}+14$ & {$[14]$} \\
34 & Animal Meal (with L\&S) & $\mathrm{g}$ & $5.0 \mathrm{E}+05$ & $2.0 \mathrm{E}+09$ & $1.0 \mathrm{E}+15$ & {$[14]$} \\
35 & Animal Meal (without L\&S) & $\mathrm{g}$ & $5.0 \mathrm{E}+05$ & $1.7 \mathrm{E}+09$ & $8.3 \mathrm{E}+14$ & {$[14]$} \\
\hline
\end{tabular}

References for UEVs:

[1] Brown and Ulgiati, 2016; [2] After Odum, 1996; [3] Assumed from economical allocation; [4] After Brown et al., 2011; [5] After Brown and Ulgiati, 2004b; [6] After Bargigli, 2004; [7] After Bargigli and Ulgiati, 2003; [8] After Cohen et al., 2007; [9] After Ganeshan et al., 2005; [10] After Mellino et al., 2013; [11] After Buranakarn, 1998; [12] After Björklund et al., 2001; [13] After Pereira et al., 2013; [14] This Work.

Figure 7 summarizes the UEVs of the animal fat and the animal meal, with and without Labor and Services (L\&S), under the assumptions of Cases 1 (zero burden) and 2 (co-product flows); Figure 8 shows the UEV values, with and without L\&S, of the electric energy generated. 


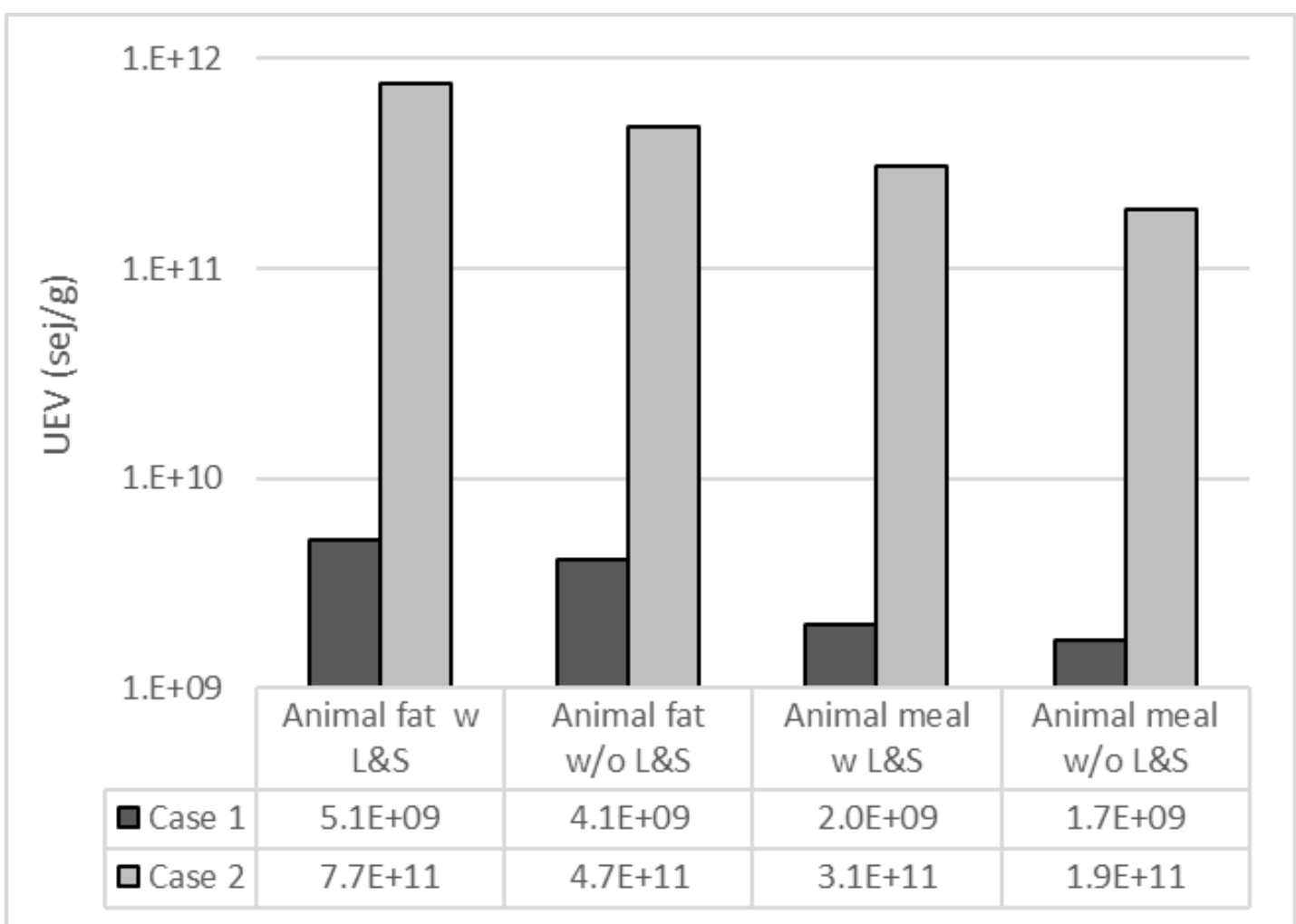

Figure $7-U E V s$ of the animal fat and of the animal meal produced by the investigated process according to the different allocation of input emergy in basic Case 1 and Case 2 scenarios.

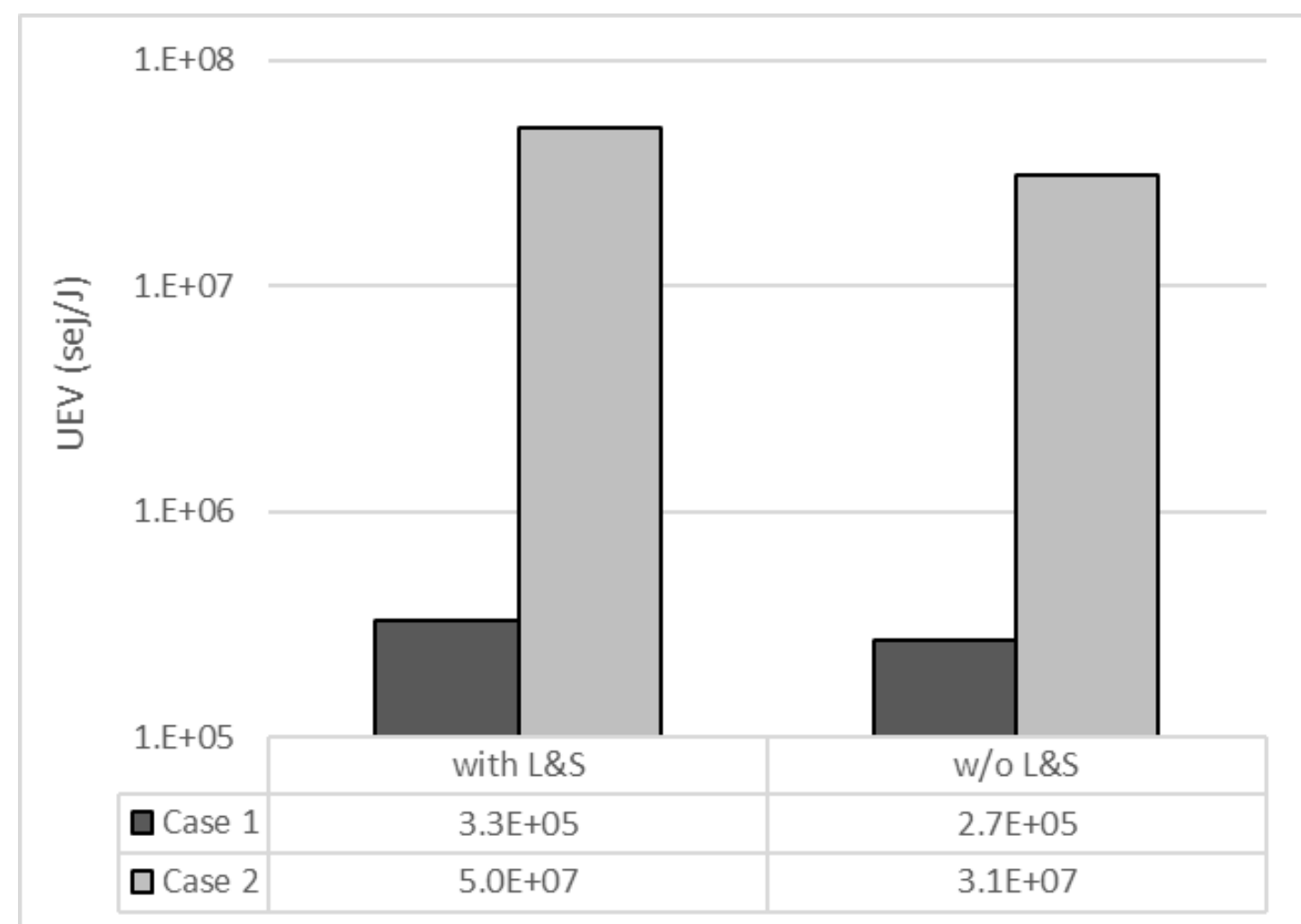

Figure 8 - UEVs of the electric energy generated by the investigated process according to the different allocation of input emergy in basic Case 1 and Case 2 scenarios.

When we move to the assumptions of Case 3 Scenario, namely we assign to the by-product outflow a fraction of total input emergy (from the livestock phase) proportional to its low 3\% of total output exergy, things become very different (according to the emergy analysis for Case 3 in Appendix B, with exergy allocation shown in Appendix A). Table 2 shows the UEVs of animal fat, animal meal and electricity under Case 3 assumptions, being one order of magnitude larger than Case 1 and one 
order of magnitude smaller than Case 2.

Table 2 - UEV values of animal fat, animal meal and electricity from Case 3

\begin{tabular}{cc|cc|cc}
\hline \multicolumn{2}{c|}{$\begin{array}{c}\text { Animal Fat } \\
\text { (sej/g) }\end{array}$} & \multicolumn{2}{c|}{$\begin{array}{c}\text { Animal Meal } \\
(\mathbf{s e j} / \mathbf{g})\end{array}$} & \multicolumn{2}{c}{$\begin{array}{c}\text { Electricity } \\
(\mathbf{s e j} / \mathbf{J})\end{array}$} \\
\hline With L\&S & Without L\&S & With L\&S & Without L\&S & With L\&S & Without L\&S \\
$5.5 \mathrm{E}+10$ & $3.4 \mathrm{E}+10$ & $2.2 \mathrm{E}+10$ & $1.4 \mathrm{E}+10$ & $3.5 \mathrm{E}+06$ & $2.2 \mathrm{E}+06$ \\
\hline
\end{tabular}

\section{Discussion}

The presented results confirm the importance of the perspective adopted during the assessment (scale, assumptions, inclusion of L\&S). In order to provide new insights to inform the LCA-EMA ongoing debate, different assumptions have been made in this study, relative to the animal by-products entering the process. When the animal by-products are considered as waste and a 'zero burden' approach is used, meaning that the material enters the process without the burdens related to the livestock and slaughtering phases (Case 1), the electricity generated shows similar performances than the Italian electricity mix. In Table 3, UEVs of electric energy from the three cases presented are compared to (i) the UEV of Italian energy mix (after Brown and Ulgiati, 2004), (ii) the UEV of electricity generated by an oil-fired power plant (after Brown et al., 2012) and (iii) the UEV of electricity from photovoltaic system (after Brown et al., 2012).

Case 1 assumption is equivalent to considering the investigated process simply as a waste disposal process, with a 'zero burden' approach: the electricity generated is comparable with the Italian electricity mix generated for the greater part using natural gas (Itten et al., 2012) as well as with electricity from the reference oil fired power plant. Instead, when the investigated case is considered as a production process, the animal feedstock is assigned an UEV of $1.33 \mathrm{E}+11 \mathrm{sej} / \mathrm{g}$ (Ghisellini et al., 2014) and carries an emergy investment of $9.37 \mathrm{E}+16 \mathrm{sej} / \mathrm{MWh}$, related to the livestock phase, this choice translates into an increase of the UEV of the generated electricity. In a like manner the UEV increases also in case 3 scenario, although to a smaller extent, due to the partial allocation of the total emergy to the electricity, via animal fat conversion. The UEVs of Case 2 and Case 3 are higher than both the Italian electricity mix and the electricity generated by the oil-fired power plant. The lower UEV value is always the one relative to the photovoltaic-generated electricity, confirming that electricity from waste recovery cannot be considered a truly renewable source, being highly supported by fossil fuels inputs. Therefore, the investigated process is not intended to compete with renewable energy sources, but rather as an example of a self-sustaining process capable to accomplish an important environmental task (i.e. the disposal of animal by-products), within a circular perspective without, at least, generating an additional burden.

Table 3 - UEVs of electric energy, without $L \& S$, from Case 1, Case 2, Case 3, oil fired power plant and photovoltaic system (sej/J).

\begin{tabular}{cccccc}
\hline Case 1 & Case 2 & Case 3 & Italian Mix & Oil power-plant & Photovoltaic \\
\hline $2.7 \mathrm{E}+05$ & $3.1 \mathrm{E}+07$ & $2.2 \mathrm{E}+06$ & $2.1 \mathrm{E}+05$ & $4.1 \mathrm{E}+05$ & $6.3 \mathrm{E}+04$ \\
\hline
\end{tabular}

If we shift from the cost of the generation of the output product to an estimate of the cost for disposal of the input waste and residues, Table 4 shows the total emergy demand (with and without L\&S) for the production of $1 \mathrm{MWh}$ from $1800 \mathrm{~kg}$ of animal waste in Case 1, compared with the disposal of an equivalent amount of municipal solid waste through landfilling and incineration (after Cherubini et al., 2008). Results from Table 4 show a slightly higher emergy demand, not considering L\&S, of Case 1 compared to conventional waste management alternatives. However, the added value here is that for each $1800 \mathrm{~kg}$ of animal by-products disposed of, the circular process Case 1 provides $1 \mathrm{MWh}$ of electric energy, $201 \mathrm{~kg}$ of purified animal fat and $497 \mathrm{~kg}$ of animal meal, as a useful output to be sold to the market. The situation is similar for Case 2 and Case 3 scenarios, although they show higher emergy costs per unit of output electricity. 
Table 4 -Comparison of the emergy demand (sej) of alternative patterns for the disposal of the same amount of animal by-products $(1800 \mathrm{~kg})$ needed to generate $1 \mathrm{MWh}$ of electric energy in CASE 1-A.

\begin{tabular}{cc|cc|cc}
\hline \multicolumn{2}{c|}{ Case 1 } & \multicolumn{2}{c|}{ Landfilling } & \multicolumn{2}{c}{ Incineration } \\
\hline without L\&S & with L\&S & without L\&S & with L\&S & without L\&S & with L\&S \\
$8.3 \mathrm{E}+14$ & $1.0 \mathrm{E}+15$ & $2.13 \mathrm{E}+14$ & $2.16 \mathrm{E}+14$ & $2.48 \mathrm{E}+14$ & $2.50 \mathrm{E}+14$ \\
\hline
\end{tabular}

While the emergy demand for unit electricity generated (UEV) is comparable with the fossil alternative (Table 3), the investigated process still is a non-sustainable fossil-powered production pattern. This happens because most input flows to the process are based on fossil sources (see Table 1). Indeed, the meat production process is an almost totally fossil powered process, and so is the collection and transport of the animal residues to the power plant. Therefore, if we aim at improving the performance of the investigated process, it needs to be reorganized in such a way that the use of fossil sources gradually decreases in all steps, with a special focus on the collection and transport of animal materials. Anyway, it should not be disregarded, for a fair evaluation of the process, that the advantage of the conversion of animal residues is not only that the electricity generated is less resource demanding than the electricity generated using fossil sources (when considering a 'zero burden' approach), but that the process also provides animal meal used as fertilizers or as animal feeding, the production of which through alternative ways would be more expensive in resource terms. Moreover, the potential production of bio-chemicals (within the frame of a slaughterhouse-based biorefinery) might provide additional advantages in terms of avoided costs compared with the production of chemicals from fossil sources (Fiorentino et al., 2017; Jayathilakan et al., 2012). Finally, the disposal of the animal by-products as landfilled waste would have a comparable cost in both resource and economic terms (Ripa et al., 2017b, 2017a), without providing any services other than the disposal itself.

\subsection{Emergy performance indicators}

The total emergy $U$ is an extensive indicator that provides an information about the size of the investigated system (namely, its total dependence on direct and indirect environmental support); instead, the UEV is an intensive indicator expressing the increasing quality of an energy or material flow through a chain of successive convergence and transformations steps (Odum, 1996). However, an analysis only based on these two indices should not be considered complete, due to the missing information that can be provided by the broad set of emergy performance indicators addressing scale dependence, self-reliance, convergence, and renewability (EYR, ELR, ESI and \%Ren). Table 5 shows these results for the Case 3 scenario, with and without L\&S. It is clear that Table 5 performances are consistent with a highly agro-industrial process, hardly sustainable, being based on large inflows of nonrenewable and intensive resources, and almost no renewable inflows. This translates, for example, into an ELR enormously high, indicating a huge pressure of non-local non-renewable inputs (F) applied to the small area dedicated to the process, causing the ELR (and all others indicators) to reflect the nature of a process carried out not because of its environmental feasibility, but for the advantage achieved in the disposal of a waste flow that otherwise might have been treated in more dangerous ways.

Table 5 - Emergy indicators calculated for Case 3 scenario.

\begin{tabular}{lcc}
\hline Emergy indicators & With L\&S & Without L\&S \\
\hline EYR & 1.001 & 1.002 \\
ELR & $1.3 \mathrm{E}+06$ & $7.9 \mathrm{E}+05$ \\
ESI & $8.0 \mathrm{E}-07$ & $1.3 \mathrm{E}-06$ \\
$\%$ Ren & $0.0001 \%$ & $0.0001 \%$ \\
\hline
\end{tabular}

Table 5 results, only focusing at the local scale of the process, do not provide a true picture of its sustainability, in that i) they disregard the fact that imported resources have been processed elsewhere (also relying on elsewhere renewable resource use) and ii) the investigated waste disposal/conversion 
service is provided to a much larger scale of users than just the local operators.

An increased sustainability does not come for free. It is reasonable that the intensity of resource use is diluted and averaged over a much larger area, e.g. in our case, the regional one. In so doing, not only the actual area served is considered, but the accounting also includes the related supporting ecosystem services and indirect resources (i.e. streets, infrastructures, offices, government). Therefore, it makes sense to consider the environmental resources of this wider area to 'dilute' the burdens of the process. The additional renewable emergy can be computed in many ways (i.e. calculating a larger area for $\mathrm{CO}_{2}$ uptake or for dilution of emissions by wind and rain), according to Brown and Ulgiati (2001), Lou et al. (2015), Viglia et al. (2017). Accounting for the renewable fraction of input flows all over the supply chain (be it regional, national or any differently shaped) means stating that a fraction of the related broader area must be set aside, to act as a buffer and dilution ecosystem in support of the excess intensity of the local process. Increasing the demand for ecosystem services to counteract the burdens related to a system, means expanding the area providing these services. This can be achieved, as mentioned in the above Section 2.2, by splitting the emergy F of imported input flows (i.e. L\&S, animal by-products) into $F_{R}$ (Renewable imported inputs) and $F_{N}$ (Non-Renewable imported inputs). Indicators calculated accordingly are averaged over the scale of the served region, in so providing a sustainability assessment of the entire supply chain, not just the local process. Table 6 provides the resulting indicators under this broader perspective. The performance improvement is very visible due to the renewable contribution of the entire area served. It is not to be disregarded that the most complete evaluation of the process is the one including L\&S, without which the process would not take place. Instead, results without L\&S only provide an assessment in terms of raw resources that may help understanding the extent the process is based on larger and local scale respectively, for appropriate policy decisions.

Table 6 - Emergy indicators calculated for Case 3 scenario under a larger scale assumption.

\begin{tabular}{lcc}
\hline Emergy indicators & With L\&S & Without L\&S \\
\hline EYR & 1.001 & 1.002 \\
ELR & 13.04 & 43.30 \\
ESI & 0.08 & 0.02 \\
\%Ren & $7.7 \%$ & $2.3 \%$ \\
\hline
\end{tabular}

As a consequence, the assumption that a larger ecosystem is needed in support of any kind of intensive process translates into a constraint placed by land availability to economic processes, be they production of goods and services, be they recovery and reuse of end-of-life waste streams. The amount of set aside land can be roughly calculated as the ratio of total emergy demand $U$ in Case 3

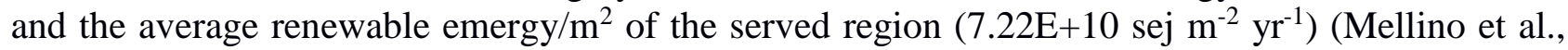
2014), yielding $1.5 \mathrm{E}+05 \mathrm{~m}^{2}$, namely about 10 times the area of the plant. This is a clear policy indication, in that associates the sustainability of production and consumption patterns to the availability of ecosystem services from buffer land, calculated via the emergy value of resources. Lack of available land translates into impossibility of further growth as well as into the need for more resource efficient processes.

\subsection{A Circular Economy Perspective}

The presented results show, first of all, that the investigated process cannot be conceived only as an electricity generation system. In Case 2 , the investigated process is only a component of a much larger framework accounting also for the agricultural phase. In this situation, the recovery of electricity is much less significant in terms of impacts than the whole system. In a 'zero burden' perspective (Case 1) the animal by-products input does not carry any burden, as it is considered a waste flow. In this case, the investigated system is not considered as purposefully oriented to generate a 'fuel' to be converted into electricity. Power generated is an additional asset produced simultaneously to the disposal operations of organic waste. Assigning all burdens to the main outputs (i.e. meat and dairy products) is coherent and legitimate: the purpose of livestock farming is not generation of electric 
energy, but food production. In so doing, being waste materials no more affected by undue burdens, the investigated system can be referred to as a feasible operation to yield a certain amount of energy with a lower burden compared to the Italian electricity mix.

Within the Circular Economy (CE) concept supported in this study, the fundamental idea is to overcome the old linear paradigm, towards a more efficient use of available resources, thus bringing an increased wellbeing through minimum environmental costs. (Ellen MacArthur Foundation, 2012; Ghisellini et al., 2016). CE gained increasing recognition in last years, aiming at maintaining a high value of products while promoting feedback and exchange flows to reduce environmental impacts, while maximizing resource efficiency (Saavedra et al., 2018). The result of the presented work has to be well interpreted. Livestock is not raised for electricity production, and the presented results are not proposing new patterns for electricity generation. Adopting a larger scale perspective, the process is a way for an improved sustainability in a larger system by looping material and energy, lowering the fraction of something that otherwise would be considered as a harmful waste.

\subsection{The added value of the Emergy Accounting approach}

EMA, complementing conventional cumulative energy demand and life cycle assessment methods, broadens the scale of the assessment from the local process boundary to the larger biosphere scale. This helps understanding how the local process is linked to resource generation over time, to the free supply of renewable ecosystem services, to the resource cost of infrastructures supporting the larger dynamics of the economy as well as the resource demand for direct and indirect labor (respectively accounted for as Labor and Services) supporting a process. Moreover, Emergy indicators provide an overview of the "local versus imported" alternative, as well as a measure of the disturbance to the local environment generated by the investment of outside sources and the actual renewability of all driving sources, to converge into an environmental sustainability indicator that considers the role of natural capital and ecosystem services for society and economic growth (Odum and Odum, 2000). In so doing it offers an environmental perspective to purely monetary or energy evaluations, thus complementing mono-dimensional assessments and providing full understanding of the links of a process with the past and surrounding environment.

In particular, the UEV (Unit Emergy Value) expresses the convergence of material, energy and information towards the final product of a process, providing a quantitative evaluation of the complexity and the efficient use of resources within and around the process. This can be considered a new and more comprehensive form of eco-efficiency, to lead towards appropriate use of resources, increased circularity and networking for resource reuse and exchange.

Through EMA, stakeholders and policy makers receive much more information about the process than just its cost in monetary terms, that is subject to market fluctuations, sectoriality and volatility. If money works well at the grocery store, it does not sufficiently support choices that involve past, present and future dynamics of societies and wellbeing, resource use and environmental integrity. Assessing the benefits only in terms of direct economic return prevents from a proper understanding of the complexity interconnecting economic development, ecosystem services, and human well-being.

\section{Conclusions}

A complete and comprehensive assessment of electric energy generation from animal by-products and the related burdens and benefits is performed through emergy perspective.

The environmental performances of selected scenarios for the production of electricity from animal fats, resulting from the processing of animal waste, were shown. This work showed that, adopting a zero burden perspective, the electric energy produced by the presented process is comparable with, among others, the average grid electricity mix.

The investigated process shows, from a bio-refinery perspective, the benefits of processing organic by-products to generate power. This process resulted valuable from an energy and environmental point of view, in order to achieve an improvement of resource and energy use throughout the entire supply chain, increasing the overall circularity of the system. 
CE results in the best effort when using limited resources, accounting also for lifestyle aspects, which become important in the societal paradigm shift. Human efforts can provide valuable benefits not only through recycling, but also through repair and recovery of goods, collaborative consumption and eco-design and through other practices important to couple the technological features for energy and material recovery.

\section{Acknowledgements}

The Authors gratefully acknowledge the financial support received from the EU Project 'EUFORIE - European Futures for Energy Efficiency', funded under H2020-EU.3.3.6. - Robust decision making and public engagement. The Authors also acknowledge the contribution of the Italian Ministry of Foreign Affairs and International Cooperation (MAECI, High Relevance Bilateral Projects), General Directorate for the Promotion of the Country System (grant No. PGR00954), and the Sino-Italian Cooperation of China Natural Science Foundation (CNSC, grant No. 7171101135), the National Natural Science Foundation of China (Grant No. 71673029) the 111 Project (No. B17005). The Authors are very indebted with Proteg S.P.A., Napoli, for kindly making process data available.

\section{References}

Adewale, P., Dumont, M.-J., Ngadi, M., 2015. Recent trends of biodiesel production from animal fat wastes and associated production techniques. Renew. Sustain. Energy Rev. 45, 574-588. https://doi.org/10.1016/j.rser.2015.02.039

Agostinho, F., Almeida, C.M.V.B., Bonilla, S.H., Sacomano, J.B., Giannetti, B.F., 2013. Urban solid waste plant treatment in Brazil: Is there a net emergy yield on the recovered materials? Resour. Conserv. Recycl. 73, 143-155. https://doi.org/10.1016/j.resconrec.2013.02.001

Alptekin, E., Canakci, M., Ozsezen, A.N., Turkcan, A., Sanli, H., 2015. Using waste animal fat based biodiesels-bioethanol-diesel fuel blends in a DI diesel engine. Fuel 157, 245-254. https://doi.org/10.1016/j.fuel.2015.04.067

Archivio Meteo Italia - Archivio meteo delle città italiane [WWW Document], n.d. URL http://archivio-meteo.distile.it/ (accessed 5.3.18).

Ariyaratne, W.K.H., Melaaen, M.C., Eine, K., Tokheim, L.A., 2010. Meat and Bone Meal as a Renewable Energy Source in Cement Kilns: Investigation of Optimum Feeding Rate, in: International Conference on Renewable Energies and Power Quality. European Association for the Development of Renewable Energies, Environment and Power Quality, Las Palmas de Gran Canaria.

Bargigli, S., 2004. Enhancing MFA And LCA Techniques by Means of Integrated Upstream and Downstream Flow Evaluation. The Case of Aluminum Production., in: Walter Leal Filho/Arnold Ubelis (Ed.), E International Conference "Integrative Approaches towards Sustainability in the Baltic Sea Region - Environmental Education, Communication and Sustainability. Peter Lang Europäischer Verlag der Wissenschaften, Frankfurt am Main, p. vol. 15, pp. 491-499.

Bargigli, S., Ulgiati, S., 2003. Emergy and Life-Cycle Assessment of Steel Production in Europe, in: Brown, M.T., Ulgiati, S., Odum, H.T., Tilley, D. (Eds.), EMERGY SYNTHESIS 2: Theory and Applications of the Emergy Methodology. The Center for Environmental Policy, Department of Environmental Engineering Sciences, University of Florida, Gainesville.

Behçet, R., Oktay, H., Çakmak, A., Aydin, H., 2015. Comparison of exhaust emissions of biodiesel-diesel fuel blends produced from animal fats. Renew. Sustain. Energy Rev. 46, 157165. https://doi.org/10.1016/j.rser.2015.02.015

Björklund, J., Geber, U., Rydberg, T., 2001. Emergy analysis of municipal wastewater treatment and generation of electricity by digestion of sewage sludge. Resour. Conserv. Recycl. 31, 293316. https://doi.org/10.1016/S0921-3449(00)00091-4

Bösch, P., Modarresi, A., Friedl, A., 2012. Comparison of combined ethanol and biogas polygeneration facilities using exergy analysis. Appl. Therm. Eng. 37, 19-29. https://doi.org/10.1016/J.APPLTHERMALENG.2011.12.048 
Brown, M.., Ulgiati, S., 1997. Emergy-based indices and ratios to evaluate sustainability: monitoring economies and technology toward environmentally sound innovation. Ecol. Eng. 9, 51-69. https://doi.org/10.1016/S0925-8574(97)00033-5

Brown, M.T., 2015. Emergy and Form: Accounting Principles for Recycle Pathways. J. Environ. Account. Manag. 3, 259-274. https://doi.org/10.5890/JEAM.2015.03.004

Brown, M.T., Buranakarn, V., 2003. Emergy indices and ratios for sustainable material cycles and recycle options. Resour. Conserv. Recycl. 38, 1-22. https://doi.org/10.1016/S09213449(02)00093-9

Brown, M.T., Campbell, D.E., De Vilbiss, C., Ulgiati, S., 2016. The geobiosphere emergy baseline: A synthesis. Ecol. Modell. 339, 92-95. https://doi.org/10.1016/j.ecolmodel.2016.03.018

Brown, M.T., Protano, G., Ulgiati, S., 2011. Assessing geobiosphere work of generating global reserves of coal, crude oil, and natural gas. Ecol. Modell. 222, 879-887. https://doi.org/10.1016/j.ecolmodel.2010.11.006

Brown, M.T., Raugei, M., Ulgiati, S., 2012. On boundaries and "investments" in Emergy Synthesis and LCA: A case study on thermal vs. photovoltaic electricity. Ecol. Indic. 15, 227-235. https://doi.org/10.1016/j.ecolind.2011.09.021

Brown, M.T., Ulgiati, S., 2016. Emergy assessment of global renewable sources. Ecol. Modell. 339, 148-156. https://doi.org/10.1016/j.ecolmodel.2016.03.010

Brown, M.T., Ulgiati, S., 2004a. Emergy analysis and environmental accounting, in: Encyclopedia of Energy. Elsevier, pp. 329-354. https://doi.org/10.1016/B0-12-176480-X/00242-4

Brown, M.T., Ulgiati, S., 2004b. Energy quality, emergy, and transformity: H.T. Odum's contributions to quantifying and understanding systems. Ecol. Modell. 178, 201-213. https://doi.org/10.1016/j.ecolmodel.2004.03.002

Brown, M.T., Ulgiati, S., 2002. Emergy evaluations and environmental loading of electricity production systems. J. Clean. Prod. 10, 321-334. https://doi.org/10.1016/S09596526(01)00043-9

Brown, M.T., Ulgiati, S., 2001. Emergy Measures of Carrying Capacity to Evaluate Economic Investments. Popul. Environ. 22, 471-501. https://doi.org/10.1023/A:1010756704612

Buranakarn, V., 1998. Evaluation of Recycling and Reuse of Building Materials Using the Emergy Analysis Method. University of Florida.

Caiado, R.G.G., de Freitas Dias, R., Mattos, L.V., Quelhas, O.L.G., Leal Filho, W., 2017. Towards sustainable development through the perspective of eco-efficiency - A systematic literature review. J. Clean. Prod. 165, 890-904. https://doi.org/10.1016/J.JCLEPRO.2017.07.166

California Water \& Land Use Partnership, 2006. How Urbanization Affects the Water Cycle.

Campbell, D.E., 2016. Emergy baseline for the Earth: A historical review of the science and a new calculation. Ecol. Modell. 339, 96-125. https://doi.org/10.1016/j.ecolmodel.2015.12.010

CDP, 2017. The Carbon Majors Database - CDP Carbon Majors Report 2017.

CEN, 2006a. UNI EN ISO 14040 - Environmental management - Life cycle assessment - Principles and framework.

CEN, 2006b. ISO 14044: Life cycle assessment - Requirements and guidelines. Int. Organ. Stand. https://doi.org/10.1136/bmj.332.7550.1107

Chakraborty, R., Gupta, A.K., Chowdhury, R., 2014. Conversion of slaughterhouse and poultry farm animal fats and wastes to biodiesel: Parametric sensitivity and fuel quality assessment. Renew. Sustain. Energy Rev. 29, 120-134. https://doi.org/10.1016/j.rser.2013.08.082

Chen, R., Qin, Z., Han, J., Wang, M., Taheripour, F., Tyner, W., O’Connor, D., Duffield, J., 2018. Life cycle energy and greenhouse gas emission effects of biodiesel in the United States with induced land use change impacts. Bioresour. Technol. 251, 249-258. https://doi.org/10.1016/J.BIORTECH.2017.12.031

Cherubini, F., Bargigli, S., Ulgiati, S., 2008. Life cycle assessment of urban waste management: energy performances and environmental impacts. The case of Rome, Italy. Waste Manag. 28, 2552-64. https://doi.org/10.1016/j.wasman.2007.11.011

Cherubini, F., Strømman, A.H., Ulgiati, S., 2011. Influence of allocation methods on the 
environmental performance of biorefinery products - A case study. Resour. Conserv. Recycl. 55, 1070-1077. https://doi.org/10.1016/j.resconrec.2011.06.001

CNR - Istituto di Geoscienze e Georisorse, n.d. Geothopica - Banca Dati Nazionale Geotermica [WWW Document]. URL

http://repo.igg.cnr.it/wm_geothopica/map.phtml?winsize=large\&language=it\&config= (accessed 5.3.18).

Cohen, M.J., Sweeney, S., Brown, M.T., 2007. Computing the Unit Emergy Value of Crustal Elements, in: Brown, M.T., Bardi, E., Campbell, D.E., Haung, S.-L., Ortega, E., Rydberg, T., Tilley, D., Ser (Eds.), EMERGY SYNTHESIS 4: Theory and Applications of the Emergy Methodology. The Center for Environmental Policy, Department of Environmental Engineering Sciences, University of Florida, Gainesville.

Corcelli, F., Ripa, M., Ulgiati, S., 2017. End-of-life treatment of crystalline silicon photovoltaic panels. An emergy-based case study. J. Clean. Prod. 161, 1129-1142. https://doi.org/10.1016/J.JCLEPRO.2017.05.031

CREA, 2013. Tabelle di composizione degli alimenti. https://doi.org/10.1007/978-3-642-829895_11

De Vilbiss, C., Brown, M.T., Siegel, E., Arden, S., 2016. Computing the geobiosphere emergy baseline: A novel approach. Ecol. Modell. 339, 133-139. https://doi.org/10.1016/j.ecolmodel.2016.05.002

Devaraj, K., Aathika, S., Mani, Y., Thanarasu, A., Periyasamy, K., Periyaraman, P., Velayutham, K., Subramanian, S., 2018. Experimental investigation on cleaner process of enhanced fat-oil extraction from alkaline leather fleshing waste. J. Clean. Prod. 175, 1-7. https://doi.org/10.1016/J.JCLEPRO.2017.11.089

Díaz-Villavicencio, G., Didonet, S.R., Dodd, A., 2017. Influencing factors of eco-efficient urban waste management: Evidence from Spanish municipalities. J. Clean. Prod. 164, 1486-1496. https://doi.org/10.1016/J.JCLEPRO.2017.07.064

EC, 2018a. DIRECTIVE (EU) 2018/2001 of the European Parliament and of the Council of 11 December 2018 on the promotion of the use of energy from renewable sources.

EC, 2018b. DIRECTIVE (EU) 2018/2002 of the European Parliament and of the Council of 11 December 2018 amending Directive 2012/27/EU on energy efficiency.

EC, 2018c. REGULATION (EU) 2018/1999 of the European Parliament and of the Council of 11 December 2018 on the Governance of the Energy Union and Climate Action, amending Regulations (EC) No 663/2009 and (EC) No 715/2009 of the European Parliament and of the Council,.

EC, 2008. Directive 2008/98/EC on waste and repealing certain Directives.

Ellen MacArthur Foundation, 2012. Towards the Circular Economy Vol. 1 - An economic and business rationale for an accelerated transition.

Eurostat, 2012. Greenhouse gas emission statistics - Statistics Explained [WWW Document]. URL http://ec.europa.eu/eurostat/statistics-explained/index.php/Greenhouse_gas_emission_statistics (accessed 10.15.15).

Evangelisti, S., Lettieri, P., Clift, R., Borello, D., 2015. Distributed generation by energy from waste technology: A life cycle perspective. Process Saf. Environ. Prot. 93, 161-172. https://doi.org/10.1016/j.psep.2014.03.008

Finnveden, G., 1999. Methodological aspects of life cycle assessment of integrated solid waste management systems. Resour. Conserv. Recycl. 26, 173-187.

Fiorentino, G., Ripa, M., Ulgiati, S., 2017. Chemicals from biomass: technological versus environmental feasibility. A review. Biofuels, Bioprod. Biorefining 11, 195-214. https://doi.org/10.1002/bbb.1729

Forster-Carneiro, T., Berni, M.D., Dorileo, I.L., Rostagno, M.A., 2013. Biorefinery study of availability of agriculture residues and wastes for integrated biorefineries in Brazil. Resour. Conserv. Recycl. 77, 78-88. https://doi.org/10.1016/j.resconrec.2013.05.007

Gaines, L., Stodolsky, F., Cuenca, R., Eberhardt, J., 1998. Life Cycle Analysis for Heavy Vehicles, 
in: Conference Paper, Air \& Waste Management Association Annual Meeting. San Diego.

Gala, A.B., Raugei, M., Ripa, M., Ulgiati, S., 2015. Dealing with waste products and flows in life cycle assessment and emergy accounting: Methodological overview and synergies. Ecol.

Modell. https://doi.org/10.1016/j.ecolmodel.2015.03.004

Ganeshan, P., Tilley, D.T., 2005. Emergy Evaluation of Air Biofilters for Carbon Monoxide Removal, in: Brown, M.T., Bardi, E., Campbell, D.E., Comar, V., Haung, S.-L., Rydberg, T., Tilley, D., Ulgiati, S. (Eds.), EMERGY SYNTHESIS 3: Theory and Applications of the Emergy Methodology. The Center for Environmental Policy, Department of Environmental Engineering Sciences, University of Florida, Gainesville.

Ghisellini, P., Cialani, C., Ulgiati, S., 2016. A review on circular economy: The expected transition to a balanced interplay of environmental and economic systems. J. Clean. Prod. https://doi.org/10.1016/j.jclepro.2015.09.007

Ghisellini, P., Protano, G., Viglia, S., Gaworski, M., Setti, M., 2014. Integrated Agricultural and Dairy Production within a Circular Economy Framework. A Comparison of Italian and Polish Farming Systems. J. Environ. Account. Manag. 2, 372-391. https://doi.org/10.5890/JEAM.2014.10.007

Giampietro, M., Martin, J.R., Ulgiati, S., 2012. Can we break the addiction to fossil energy? Energy 37, 2-4. https://doi.org/10.1016/j.energy.2011.11.001

Hagman, L., Blumenthal, A., Eklund, M., Svensson, N., 2017. The role of biogas solutions in sustainable biorefineries. J. Clean. Prod. https://doi.org/10.1016/J.JCLEPRO.2017.03.180

Haines, R.J., 2004. Farm to fork - A strategy for meat safety in Ontario - Report of the meat regulatory and inspection review.

He, F., Miao, X., Wong, C.W.Y., Lee, S., 2018. Contemporary corporate eco-innovation research: A systematic review. J. Clean. Prod. 174, 502-526. https://doi.org/10.1016/J.JCLEPRO.2017.10.314

Herd, D.B., Sprott, L.R., 1986. Body condition, nutrition and reproduction of beef cows. Texas Agric. Ext. Serv.

Ingwersen, W.W., 2011. Emergy as a life cycle impact assessment indicator. A goldmining case study. J. Ind. Ecol. 15, 550-567.

Itten, R., Frischknecht, R., Stucki, M., 2012. Life Cycle Inventories of Electricity Mixes and Grid. Uster.

Jayathilakan, K., Sultana, K., Radhakrishna, K., Bawa, A.S., 2012. Utilization of byproducts and waste materials from meat, poultry and fish processing industries: a review. J. Food Sci. Technol. 49, 278-93. https://doi.org/10.1007/s13197-011-0290-7

Jørgensen, A., Bikker, P., Herrmann, I.T., 2012. Assessing the greenhouse gas emissions from poultry fat biodiesel. J. Clean. Prod. 24, 85-91. https://doi.org/10.1016/J.JCLEPRO.2011.11.011

JRC, 2010. International Reference Life Cycle Data System (ILCD) Handbook -- General guide for Life Cycle Assessment -- Detailed guidance, Constraints. Publications Office of the European Union, Luxembourg. https://doi.org/10.2788/38479

Kumar, M.S., Kerihuel, A., Bellettre, J., Tazerout, M., 2006. A Comparative Study of Different Methods of Using Animal Fat as a Fuel in a Compression Ignition Engine. J. Eng. Gas Turbines Power 128. https://doi.org/10.1115/1.2180278

Kursun, B., Bakshi, B.R., Mahata, M., Martin, J.F., 2015. Life cycle and emergy based design of energy systems in developing countries: Centralized and localized options. Ecol. Modell. 305, 40-53. https://doi.org/10.1016/J.ECOLMODEL.2015.03.006

Liu, X., Ziv, G., Bakshi, B.R., 2018a. Ecosystem services in life cycle assessment - Part 1: A computational framework. J. Clean. Prod. 197, 314-322. https://doi.org/10.1016/j.jclepro.2018.06.164

Liu, X., Ziv, G., Bakshi, B.R., 2018b. Ecosystem services in life cycle assessment - Part 2: Adaptations to regional and serviceshed information. J. Clean. Prod. 197, 772-780. https://doi.org/10.1016/j.jclepro.2018.05.283 
Lou, B., Qiu, Y., Ulgiati, S., 2015. Emergy-based indicators of regional environmental sustainability: A case study in Shanwei, Guangdong, China. Ecol. Indic. 57, 514-524. https://doi.org/10.1016/J.ECOLIND.2015.03.017

Mackenzie, S.G., Leinonen, I., Kyriazakis, I., 2017. The need for co-product allocation in the life cycle assessment of agricultural systems - is "biophysical" allocation progress? Int. J. Life Cycle Assess. 22, 128-137. https://doi.org/10.1007/s11367-016-1161-2

Martire, S., Mirabella, N., Sala, S., 2017. Widening the perspective in greenhouse gas emissions accounting: The way forward for supporting climate and energy policies at municipal level. J. Clean. Prod. https://doi.org/10.1016/j.jclepro.2017.12.055

Marvuglia, A., Benetto, E., Rios, G., Rugani, B., 2013. SCALE: Software for CALculating Emergy based on life cycle inventories. Ecol. Modell. 248, 80-91. https://doi.org/10.1016/J.ECOLMODEL.2012.09.013

Mellino, S., Ripa, M., Ulgiati, S., 2013. Spatial Accounting of Environmental Pressure and Resource Consumption Using Night-light Satellite Imagery. J. Environ. Account. Manag. 1, 361-379. https://doi.org/10.5890/JEAM.2013.11.005

Mellino, S., Ripa, M., Zucaro, A., Ulgiati, S., 2014. An emergy-GIS approach to the evaluation of renewable resource flows: A case study of Campania Region, Italy. Ecol. Modell. 271, 103112. https://doi.org/10.1016/j.ecolmodel.2012.12.023

Nimmanterdwong, P., Chalermsinsuwan, B., Piumsomboon, P., 2018. Development of an emergy computation algorithm for complex systems using depth first search and track summing methods. J. Clean. Prod. 193, 625-641. https://doi.org/10.1016/J.JCLEPRO.2018.05.088

Odum, H.T., 2000. An Energy Hierarchy Law For Biogeochemical Cycles, in: Brown, M. et al. (Ed.), Emergy Synthesis: Theory and Applications of the Emergy Methodology - Proceedings from the First Biennial Emergy Analysis Research Conference, Gainesville, Florida, September, 1999. Gainesville, Florida, pp. 235-48.

Odum, H.T., 1996. Environmental Accounting: Emergy and Environmental Decision Making. John Wiley \& Sons, Inc., New York.

Odum, H.T., 1973. Energy, ecology, and economics. Ambio 2:6.

Odum, H.T., Odum, E.P., 2000. The Energetic Basis for Valuation of Ecosystem Services. Ecosystems. https://doi.org/10.2307/3658663

Pavan, A.L.R., Ometto, A.R., 2018. Ecosystem Services in Life Cycle Assessment: A novel conceptual framework for soil. Sci. Total Environ. 643, 1337-1347. https://doi.org/10.1016/j.scitotenv.2018.06.191

Pereira, L., Zucaro, A., Ortega, E., Ulgiati, S., 2013. Wealth, trade and the environment: Carrying capacity, economic performance and wellbeing in Brazil and Italy. J. Environ. Account. Manag. 1, 159-188. https://doi.org/10.5890/JEAM.2013.05.005

Raugei, M., Bargigli, S., Ulgiati, S., 2007. "Nested Emergy Analyses": Moving Ahead from the Spreadsheet Platform, in: Brown, M.T., Bardi, E., Campbell, D.E., Haung, S.-L., Ortega, E., Rydberg, T., Tilley, D.T., Ulgiati, S. (Eds.), EMERGY SYNTHESIS 4: Theory and Applications of the Emergy Methodology. The Center for Environmental Policy, Department of Environmental Engineering Sciences, University of Florida.

Raugei, M., Rugani, B., Benetto, E., Ingwersen, W.W., 2014. Integrating emergy into LCA: Potential added value and lingering obstacles. Ecol. Modell. 271, 4-9. https://doi.org/10.1016/j.ecolmodel.2012.11.025

Reza, B., Sadiq, R., Hewage, K., 2014. Emergy-based life cycle assessment (Em-LCA) of multiunit and single-family residential buildings in Canada. Int. J. Sustain. Built Environ. 3, 207224. https://doi.org/10.1016/j.ijsbe.2014.09.001

Ripa, M., 2014. From Waste Management to Resource Management: a local challenge with global impacts. Methodological concerns and case studies within an LCA perspective. Department of Sciences and Technologies, Parthenope University of Naples - Doctoral Thesis, Naples.

Ripa, M., Fiorentino, G., Giani, H., Clausen, A., Ulgiati, S., 2017a. Refuse recovered biomass fuel from municipal solid waste. A life cycle assessment. Appl. Energy 186, 211-225. 
https://doi.org/10.1016/J.APENERGY.2016.05.058

Ripa, M., Fiorentino, G., Vacca, V., Ulgiati, S., 2017b. The relevance of site-specific data in Life Cycle Assessment (LCA). The case of the municipal solid waste management in the metropolitan city of Naples (Italy). J. Clean. Prod. 142, 445-460. https://doi.org/10.1016/J.JCLEPRO.2016.09.149

Rugani, B., Benetto, E., 2012. Improvements to Emergy Evaluations by Using Life Cycle Assessment. Environ. Sci. Technol. 46, 4701-4712. https://doi.org/10.1021/es203440n

Rugani, B., Maes, J., Othoniel, B., Pulselli, F.M., Schaubroeck, T., Ziv, G., 2018. Human-nature nexuses: Broadening knowledge on integrated biosphere-technosphere modelling to advance the assessment of ecosystem services. Ecosyst. Serv. 30, 193-199. https://doi.org/10.1016/j.ecoser.2018.04.002

Saavedra, Y.M.B., Iritani, D.R., Pavan, A.L.R., Ometto, A.R., 2018. Theoretical contribution of industrial ecology to circular economy. J. Clean. Prod. 170, 1514-1522. https://doi.org/10.1016/J.JCLEPRO.2017.09.260

Santagata, R., Ripa, M., Ulgiati, S., 2017. An environmental assessment of electricity production from slaughterhouse residues. Linking urban, industrial and waste management systems. Appl. Energy 186, 175-188. https://doi.org/10.1016/j.apenergy.2016.07.073

Spagnolo, S., Gonella, F., Viglia, S., Ulgiati, S., 2018. Venice artistic glass: Linking art, chemistry and environment - A comprehensive emergy analysis. J. Clean. Prod. 171, 1638-1649. https://doi.org/10.1016/J.JCLEPRO.2017.10.074

Talebian-Kiakalaieh, A., Amin, N.A.S., Mazaheri, H., 2013. A review on novel processes of biodiesel production from waste cooking oil. Appl. Energy 104, 683-710. https://doi.org/10.1016/j.apenergy.2012.11.061

Terry, C.A., Knapp, R.H., Edwards, J.W., Mies, W.L., Savell, J.W., Cross, H.R., 1990. Yields of by-products from different cattle types. J. Anim. Sci. 68, 4200-4205.

Tulloh, N.M., 1961. The chemical composition of cattle skin. Aust. J. Agric. Res. 12, 725-732. https://doi.org/10.1071/AR9610725

Ulgiati, S., Raugei, M., Bargigli, S., 2006. Overcoming the inadequacy of single-criterion approaches to Life Cycle Assessment. Ecol. Modell. 190, 432-442. https://doi.org/10.1016/j.ecolmodel.2005.03.022

United Nations Statistics Division, 2011. Municipal waste treatment [WWW Document]. URL $\mathrm{http}$ ///unstats.un.org/unsd/environment/wastetreatment.htm (accessed 12.7.15).

Viglia, S., Civitillo, D.F., Cacciapuoti, G., Ulgiati, S., 2018. Indicators of environmental loading and sustainability of urban systems. An emergy-based environmental footprint. Ecol. Indic. 94, 82-99. https://doi.org/10.1016/J.ECOLIND.2017.03.060

Viglia, S., Nienartowicz, A., Kunz, M., Franzese, P.P., 2013. Integrating Environmental Accounting. Life Cycle and Ecosystem Services Assessment. J. Environ. Account. Manag. 1, 307-319. https://doi.org/10.5890/JEAM.2013.11.001

Wan Alwi, S.R., Klemeš, J.J., Varbanov, P.S., 2016. Cleaner energy planning, management and technologies: Perspectives of supply-demand side and end-of-pipe management. J. Clean. Prod. https://doi.org/10.1016/j.jclepro.2016.07.181

Wang, Li, Long, Yan, Gao, Chen, Sui, 2017. Sustainability evaluation of recycling in agricultural systems by emergy accounting. Resour. Conserv. Recycl. 117, 114-124. https://doi.org/10.1016/j.resconrec.2016.11.009

Wang, S., Cao, T., Chen, B., 2017. Urban energy-water nexus based on modified input-output analysis. Appl. Energy 196, 208-217. https://doi.org/10.1016/J.APENERGY.2017.02.011

Wernet, G., Bauer, C., Steubing, B., Reinhard, J., Moreno-Ruiz, E., Weidema, B., 2016. The ecoinvent database version 3 (part I): overview and methodology. Int. J. Life Cycle Assess. pp.1218-1230.

WWF, 2016. Living Planet Report 2016 - Global Footprint Network. 



\section{Appendix A - Further details about EMA method, data and calculation procedures}

When performing an EMA, the first step is to draw a diagram of the investigated system (e.g. Figures 2, 4, 5 and 6), in order to highlight all the significant input and output flows, the storages, the components of the system and the existing relations and feedback loops; then an inventory table of inflows and outflows can be built. Emergy units are obtained multiplying input flows with the respective UEV. UEVs also define the position of the different energy flows in the systems energy hierarchy(Gala et al., 2015). The last step is the calculation of the total emergy (U) and of a set of emergy indices capable to assess scale dependence, self-reliance, convergence (Brown and Ulgiati, 1997).

Emergy inflows to a system or process are generally aggregated depending on their characteristics (Brown and Ulgiati, 2016): R (locally renewable emergy flows; e.g. rainfall, wind), N (locally nonrenewable emergy flows; e.g. topsoil, ground water), F (imported emergy flows; e.g., food, minerals, goods), so that total emergy $\mathrm{U}$ can be expressed as:

$$
\mathrm{U}=\mathrm{R}+\mathrm{N}+\mathrm{F}+\mathrm{L} \& \mathrm{~S}
$$

where L\&S are respectively the emergy supporting labor units imported from outside the system and directly applied to the process and the emergy supporting the indirect labor (i.e. labor associated to imported flows over the supply chain processes as well as the overall supporting infrastructure). Sometimes, when focus is placed on the global scale performance (i.e. the relation of the process with the larger scale where resources come from), it is useful to split the imported flows into their renewable or non-renewable fractions, $F_{R}$ and $F_{N}$. Performance indices calculated with and without splitting the imported flows into their component fractions may come out very different, in particular when the study deals with industrial processes, generally characterized by heavy dependence on nonrenewable imports. The different assumptions about scale and splitting may translate into different meaning of the calculated indicators.

\section{Emergy Algebra}

Due to the involvement of large dimensional and temporal patterns, as well as due to the complexity of environmental networks with loops and feedback flows, the calculation of emergy flows converging to each network component requires algebraic rules that are slightly different than in other biophysical accounting approaches. Emergy algebra calls split two flows deriving from the original flow (e.g. a water pipeline that splits into two pipelines of smaller size); splits have the same physicochemical nature and only differ by quantity, according to which the total emergy is proportionally assigned. Instead, co-products are flows with different physico-chemical nature that cannot be produced independently although their reciprocal proportions can be varied to some extent (e.g. electricity and hot water from a thermal power plant, corn and straw in agriculture). In this case, the total emergy is entirely assigned to each of the co-products. In order not to risk double counting, when split flows reunite downstream they can be summed, while co-product flows cannot be summed and only the largest is assigned to the downstream process. Further details on emergy algebra can be found in Brown and Ulgiati (2016). In the emergy system diagrams like the one showed in Figure 5, split flows are indicated as bifurcating pathways, while co-product flows as two or more pathways independent from each other since the very beginning. It is not uncommon, as in the case of the present process, that such a strict distinction becomes very difficult to make and some flows may be assigned both split and co-product characteristics. In this case, calculations are performed based on both options, in order to obtain a max/min range of performances.

Odum, 2000 states that material that is dispersed or recycled decreases its stored emergy, and the amount of such decrease can be estimated as the emergy required to restore its initial concentration. Brown, 2015 defines the difference between: a) product recycle, as "the return of material to a previous stage in a cyclic process"; in recycle pathways, when a material is returned to a previous stage, it loses all its emergy, according to the emergy algebra rules; b) dispersed recycle, as "the return 
of materials to the environment through actions that distribute them over wider area"; in dispersal pathways the emergy of products and materials decreases as they are dispersed and is proportional to the degree of dispersal. At background concentrations all the emergy associated to the information content (form, structure, design) is lost and only the raw emergy of matter is left. Moreover, Brown 2015 makes a distinction between product, as the result of a process that has higher quality than the starting material, co-product, as a product produced along with or jointly with a different product in a process in which both are valued, and by-product, as an incidental or secondary product in addition, but not valued as highly, to the main product.

\section{Definition of EMA indicators:}

The indicators used in this study are defined as follows (Brown and Ulgiati, 2004a).

- EYR is defined as U/F, defines the ability of a system to use local resources by importing outside resources, providing information about local-vs-imported.

- $\quad E L R=\left(N+F_{R}+F_{N}\right) /\left(R+F_{R}\right)$, matches non-renewable and imported emergy to renewable emergy. It measures the stress imposed to an ecosystem by a transformation process.

- $\mathrm{ESI}=\mathrm{EYR} / \mathrm{ELR}$, being an aggregated indicator, it compares the outside/local information to the non-renewable/renewable information, aiming at using the largest share of local resources with the minimum environmental loading.

- $\% \operatorname{Ren}=\left(\mathrm{R}+\mathrm{F}_{\mathrm{R}}\right) / \mathrm{U}$, defines the emergy fraction from renewable sources.

Data provided by the company is relative to a timespan between September and October 2014. All non-primary data has been referred to the same time span.

1. Data from Proteg S.P.A.

Plant area: $29600 \mathrm{~m}^{2}$

Collection distance: $80000 \mathrm{~km} /$ week

Water used in process: $3500 \mathrm{~m}^{3} / 3$ months

Animal material used in 3 months: $1.63 \mathrm{E}+7 \mathrm{~kg}$

Electricity produced in 3 months: $9057.75 \mathrm{MWh}$

Animal meal produced in 3 months: $4.50 \mathrm{E}+06 \mathrm{~kg}$

Animal fat produced in 3 months: $3.92 \mathrm{E}+06 \mathrm{~kg}$

Animal fat used for electricity production in 3 months: $2.11 \mathrm{E}+06 \mathrm{~kg}$

Methane used in process: $65 \mathrm{~m}^{3} /$ ton of animal material

Lorry consumption: $3 \mathrm{~km} / \mathrm{l}$

Diesel fuel used in engine in 3 months: $2.64 \mathrm{E}+03 \mathrm{~kg}$

Urea used in process: $90 \mathrm{l} / \mathrm{h}$

Lubricating oil used in 3 months: $1938.6 \mathrm{~kg}$

Time fat production: $3.37 \mathrm{E}+06 \mathrm{~s}\left(60 \frac{\mathrm{s}}{\mathrm{min}} * 60 \frac{\mathrm{min}}{\mathrm{h}} * 12 \frac{\mathrm{h}}{\text { day }} * 6 \frac{\text { days }}{\text { week }} * 13\right.$ weeks $)$

Time electricity generation: $7.86 \mathrm{E}+06 \mathrm{~s}\left(60 \frac{\mathrm{s}}{\mathrm{min}} * 60 \frac{\mathrm{min}}{\mathrm{h}} * 24 \frac{h}{\text { days }} * 91\right.$ days $)$

Human Labor: 50 people working in plant

Total investment for plant: $11250000 €$

\section{Renewables}

All renewables calculations have been performed accordingly to Brown and Ulgiati, 2016

Sun irradiation: $5.20 \mathrm{E}+07 \mathrm{~J} / \mathrm{m}^{2}$ (Archivio Meteo Italia - Archivio meteo delle città italiane)

Albedo: 0.10 (Archivio Meteo Italia - Archivio meteo delle città italiane)

Wind speed: $2.56 \mathrm{~m} / \mathrm{s}$ (Archivio Meteo Italia - Archivio meteo delle città italiane)

Rainfall: $0.156 \mathrm{~m}$ (Archivio Meteo Italia - Archivio meteo delle città italiane)

Heat flow: $0.015 \mathrm{~J} / \mathrm{s} / \mathrm{m}^{2}$ (Geothopica - Banca Dati Nazionale Geotermica, CNR) 
Evapotranspiration plant site: 30\% (California Water \& Land Use Partnership, 2006)

3. Machineries

Machinery data have been retrieved from information from Proteg S.P.A., data from manufacturers and data from ecoinvent v 3.1 database (Wernet et al., 2016).

Allocation for rendering process machinery have been calculated as follows:

Machinery life span: $12 \frac{h}{\text { day }} * 6 \frac{\text { days }}{\text { week }} * 52 \frac{\text { weeks }}{y r} * 10$ years $=3.74 E+04 h$

Time for $1 \mathrm{MWh}: \frac{12 \frac{h}{\text { day }} * 6 \frac{\text { days }}{\text { week }} * 13 \text { weeks }}{9057.75 M W h}=1.03 E-01 \frac{h}{M W h}$

Allocation: $\frac{\text { Time for } 1 \mathrm{MWh}}{\text { Machinery life span }}=2.76 \mathrm{E}-06$

Allocation for electricity generation process machinery have been calculated as follows:

Machinery life span: $24 \frac{h}{\text { day }} * 365 \frac{\text { days }}{\text { year }} * 10$ years $=8.76 E+04 h$

Time for $1 \mathrm{MWh}: \frac{24 \frac{h}{d a y} * 7 \frac{\text { days }}{\text { week }} * 13 \text { weeks }}{9057.75 M W h}=2.41 E-01 \mathrm{~h}$

Allocation: $\frac{\text { Time for } 1 M W h}{\text { Machinery life span }}=2.75 E-06$

Allocation for collection process vehicles have been calculated as follows:

Data for lorry from Gaines et al., 1998

Data for lorry lifespan from Proteg S.P.A.

26 ton lorry lifespan: $1000000 \mathrm{~km}$

Km for $1 \mathrm{MWh}: \frac{80000 \frac{\mathrm{km}}{\text { week }} * 13 \text { weeks } / 9057.75 \mathrm{MWh}}{2.6 E+07 \mathrm{~g}} * 1.8 \mathrm{E}+06 \mathrm{~g}$ (animal material for $1 \mathrm{MWh}$ )

Allocation: 7.97E-06

4. Exergy calculations

Exergy calculations has been based on the farm output flows from Ghisellini et al., 2015b, thus manure is not included since, in the chosen scenario, manure is reused as fertilizer.

Exergy of biomass components (Bösch et al., 2012):

Fat: $41954 \mathrm{~J} / \mathrm{g}$

Protein: $24488 \mathrm{~J} / \mathrm{g}$

Carbohydrates: $16687 \mathrm{~J} / \mathrm{g}$

Cow Composition (Herd and Sprott, 1986):

Total weight (Ghisellini et al., 2014): 1.76E+08 g

Fat: $16 \%$

Protein: $18 \%$ 
Water: $61 \%$

Mineral: $5 \%$

Chemical exergy: $1.96 \mathrm{E}+12 \mathrm{~J}$

Edible fraction (52\% of cow weight (Haines, 2004)) composition (CREA, 2013):

Fat: $5 \%$

Protein: $21 \%$

Water: $74 \%$

Chemical exergy: 6.72E+11 J

Skin (8\% of cow weight (Terry et al., 1990)) composition (Tulloh, 1961):

Fat: $2 \%$

Protein: $30 \%$

Water: $68 \%$

Chemical exergy: $1.13 \mathrm{E}+11 \mathrm{~J}$

Non-edible fraction ( $48 \%$ of cow weight):

Chemical exergy: Chem. exergy of live cow - chem. exergy of edible part - chem. exergy of skin $=$ $1.18 \mathrm{E}+12 \mathrm{~J}$

Milk composition (CREA, 2013):

Total weight (Ghisellini et al., 2014): 1.18E+10 g

Water: $88 \%$

Protein: $3 \%$

Fat: $4 \%$

Carbohydrates: $5 \%$

Chemical exergy: $3.65 \mathrm{E}+13 \mathrm{~J}$

\% Exergy Meat: $1.7 \%$

$\%$ Exergy By-products: $3.1 \%$

$\%$ Exergy Skin: $0.3 \%$

$\%$ Exergy Milk: $94.9 \%$

Total emergy (After Ghisellini et al., 2015b) with L\&S: 1.52E+19 sej

Total emergy without L\&S: 9.27E+18 sej

By-products output (d.m.): $3.30 \mathrm{E}+07 \mathrm{~g}$

UEV by-products (d.m.) with L\&S: $1.41 \mathrm{E}+10 \mathrm{sej} / \mathrm{g}$

UEV by-products (d.m.) without L\&S: 8.60E+09 sej/g 


\section{Appendix B}

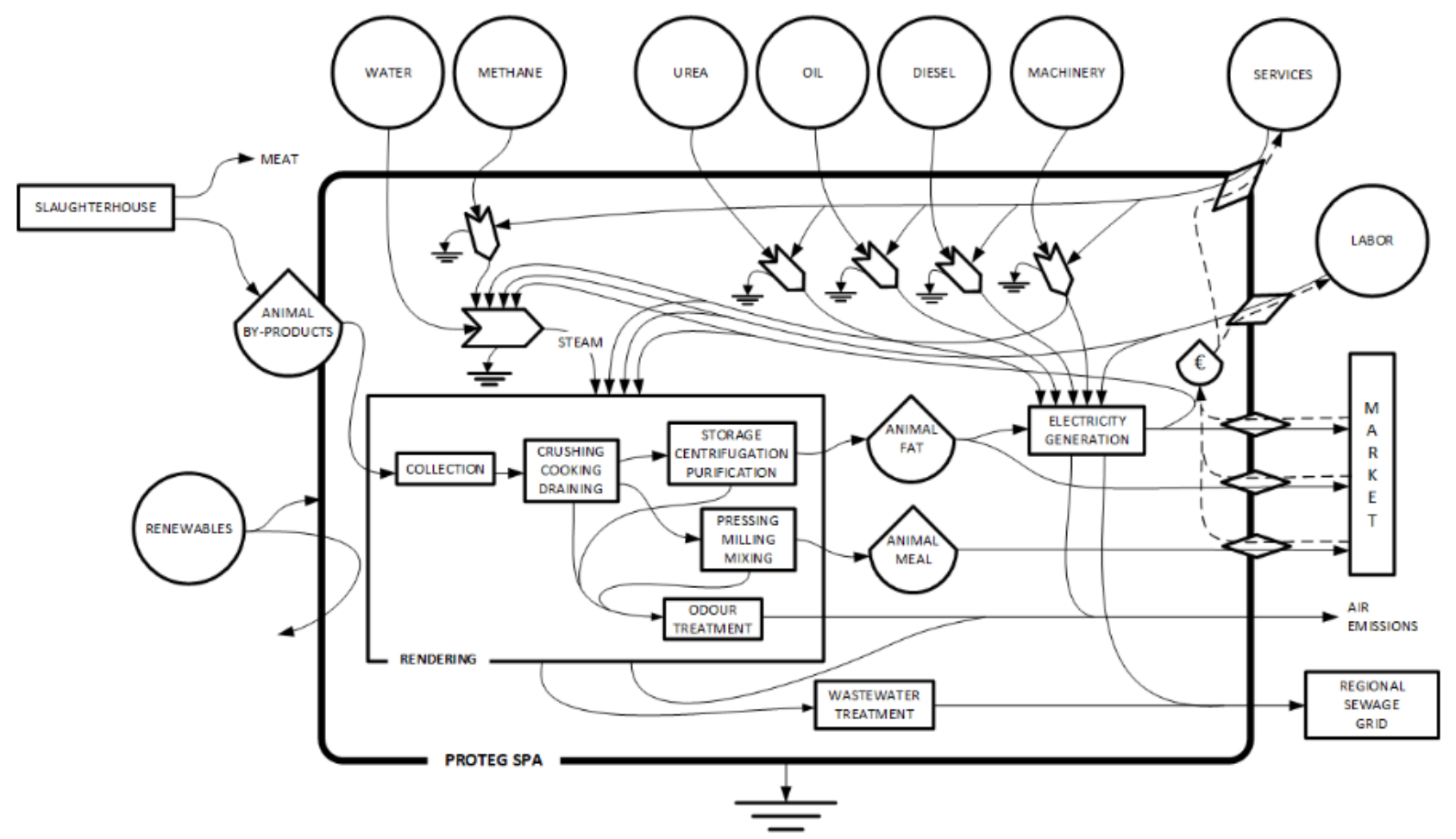

Figure B.1 - System diagram of Case 2 (where the flows from the slaughterhouse are considered as co-products).

Table B.1 - Electricity from animal by-products (CASE 2)

\begin{tabular}{|c|c|c|c|c|c|c|}
\hline$\#$ & Item & Unit & Inputs & $\begin{array}{c}\text { UEV } \\
\text { (sej/unit) }\end{array}$ & $\begin{array}{c}\text { Emergy } \\
\text { (sej/MWh) }\end{array}$ & Ref. \\
\hline \multicolumn{7}{|c|}{ R-Renewable Inputs Locally Available } \\
\hline 1 & Sun & $\mathrm{J}$ & $1.4 \mathrm{E}+08$ & $1.0 \mathrm{E}+00$ & $1.4 \mathrm{E}+08$ & Def. \\
\hline 2 & Deep Heat & $\mathrm{J}$ & $3.9 \mathrm{E}+05$ & $4.9 \mathrm{E}+03$ & $1.9 \mathrm{E}+09$ & {$[1]$} \\
\hline \multicolumn{7}{|c|}{ Secondary and tertiary renewable sources } \\
\hline 3 & Rain & $\mathbf{J}$ & $1.2 \mathrm{E}+06$ & $7.0 \mathrm{E}+03$ & $8.7 \mathrm{E}+09$ & {$[1]$} \\
\hline 4 & Wind & $\mathrm{J}$ & $4.0 \mathrm{E}+06$ & $8.0 \mathrm{E}+02$ & $3.2 \mathrm{E}+09$ & {$[1]$} \\
\hline \multicolumn{7}{|c|}{ N-Non-renewable Inputs Locally Available } \\
\hline 5 & Underground water & $\mathrm{J}$ & $5.7 \mathrm{E}+06$ & $2.3 \mathrm{E}+06$ & $1.3 \mathrm{E}+13$ & {$[2]$} \\
\hline \multicolumn{7}{|c|}{ F - Non-renewable Imported Inputs } \\
\hline 6 & Cat. 3 Material (d.m.) - w/o L\&S & g & $7.0 \mathrm{E}+05$ & $1.3 \mathrm{E}+11$ & $9.4 \mathrm{E}+16$ & [15] \\
\hline 7 & Cat. 3 Material (d.m.) - w L\&S & $\mathrm{g}$ & $7.0 \mathrm{E}+05$ & $2.2 \mathrm{E}+11$ & $1.5 \mathrm{E}+17$ & [15] \\
\hline 8 & Natural Gas & $\mathrm{J}$ & $4.2 \mathrm{E}+09$ & $1.4 \mathrm{E}+05$ & $5.9 \mathrm{E}+14$ & [4] \\
\hline 9 & Diesel for transportation & $\mathrm{J}$ & $7.1 \mathrm{E}+08$ & $1.4 \mathrm{E}+05$ & $1.0 \mathrm{E}+14$ & [4] \\
\hline 10 & Diesel for engine & $\mathrm{J}$ & $1.3 \mathrm{E}+07$ & $1.4 \mathrm{E}+05$ & $1.8 \mathrm{E}+12$ & [4] \\
\hline 11 & Lubricating oil & $\mathrm{J}$ & $9.0 \mathrm{E}+06$ & $1.1 \mathrm{E}+05$ & $1.0 \mathrm{E}+12$ & [4] \\
\hline 12 & Urea & $\mathrm{g}$ & $2.4 \mathrm{E}+04$ & $4.8 \mathrm{E}+09$ & $1.1 \mathrm{E}+14$ & [5] \\
\hline \multicolumn{7}{|c|}{ Machinery } \\
\hline 13 & Steel & g & $1.1 \mathrm{E}+03$ & $2.7 \mathrm{E}+09$ & $3.0 \mathrm{E}+12$ & [6] \\
\hline 14 & Aluminum & g & $2.6 \mathrm{E}+01$ & $4.1 \mathrm{E}+07$ & $1.1 \mathrm{E}+09$ & [6] \\
\hline
\end{tabular}




\begin{tabular}{|c|c|c|c|c|c|c|}
\hline 15 & Plastics \& Rubbers & $\mathrm{g}$ & $1.1 \mathrm{E}+02$ & $2.4 \mathrm{E}+09$ & $2.7 \mathrm{E}+11$ & {$[5]$} \\
\hline 16 & Copper & $\mathrm{g}$ & $6.8 \mathrm{E}+00$ & $5.8 \mathrm{E}+08$ & $3.9 \mathrm{E}+09$ & [6] \\
\hline 17 & Cast Iron & $\mathrm{g}$ & $1.4 \mathrm{E}+02$ & $1.9 \mathrm{E}+09$ & $2.7 \mathrm{E}+11$ & [7] \\
\hline 18 & Lead & $\mathrm{g}$ & 2.7E-01 & $3.6 \mathrm{E}+11$ & $9.9 \mathrm{E}+10$ & [8] \\
\hline 19 & Iron & $\mathrm{g}$ & $7.1 \mathrm{E}+00$ & $2.7 \mathrm{E}+09$ & $1.9 \mathrm{E}+10$ & [6] \\
\hline 20 & Glass & $\mathrm{g}$ & $2.1 \mathrm{E}-01$ & $2.5 \mathrm{E}+09$ & $5.2 \mathrm{E}+08$ & [5] \\
\hline 21 & Polypropylene & $\mathrm{g}$ & $3.7 \mathrm{E}+00$ & $2.4 \mathrm{E}+09$ & $8.9 \mathrm{E}+09$ & {$[5]$} \\
\hline 22 & Silicon Carbide & $\mathrm{g}$ & $1.5 \mathrm{E}+01$ & $2.3 \mathrm{E}+09$ & $3.4 \mathrm{E}+10$ & [9] \\
\hline 23 & Polyethylene & $\mathrm{g}$ & $2.5 \mathrm{E}+01$ & $2.4 \mathrm{E}+09$ & $6.1 E+10$ & {$[5]$} \\
\hline 24 & Concrete & $\mathrm{g}$ & $4.3 \mathrm{E}+03$ & $1.3 \mathrm{E}+09$ & $5.4 \mathrm{E}+12$ & {$[10]$} \\
\hline 25 & Limestone & $\mathrm{kg}$ & $3.9 \mathrm{E}-02$ & $2.1 \mathrm{E}+12$ & $8.3 \mathrm{E}+10$ & {$[2]$} \\
\hline 26 & Fiber Glass & $\mathrm{g}$ & $3.5 \mathrm{E}+00$ & $7.4 \mathrm{E}+09$ & $2.6 \mathrm{E}+10$ & [11] \\
\hline 27 & Rock Woll & $\mathrm{g}$ & $1.6 \mathrm{E}+00$ & $2.3 \mathrm{E}+09$ & $3.7 \mathrm{E}+09$ & {$[12]$} \\
\hline 28 & Bitumen & $\mathrm{J}$ & $3.5 \mathrm{E}+04$ & $1.4 \mathrm{E}+05$ & $4.8 \mathrm{E}+09$ & {$[4]$} \\
\hline \multicolumn{7}{|c|}{ L\&S - Information and Infrastructure } \\
\hline 29 & Labour & $\mathrm{ppl} / \mathrm{yr}$ & $1.4 \mathrm{E}-03$ & $4.4 \mathrm{E}+16$ & $6.0 \mathrm{E}+13$ & [13] \\
\hline \multirow[t]{2}{*}{30} & Services & $€$ & $7.4 \mathrm{E}+01$ & $1.7 \mathrm{E}+12$ & $1.2 \mathrm{E}+14$ & [13] \\
\hline & Output & & & & & \\
\hline \multirow[t]{2}{*}{31} & Electricity (with L\&S) & MWh & 8.6E-01 & $1.8 \mathrm{E}+17$ & $1.6 \mathrm{E}+17$ & [14] \\
\hline & & $\mathrm{J}$ & $3.1 \mathrm{E}+09$ & $5.0 \mathrm{E}+07$ & $1.6 \mathrm{E}+17$ & {$[14]$} \\
\hline \multirow[t]{2}{*}{32} & Electricity (without L\&S) & MWh & 8.6E-01 & $1.1 \mathrm{E}+17$ & $9.5 \mathrm{E}+16$ & {$[14]$} \\
\hline & & $\mathrm{J}$ & $3.1 \mathrm{E}+09$ & $3.1 \mathrm{E}+07$ & $9.5 \mathrm{E}+16$ & {$[14]$} \\
\hline 33 & Animal Fat (with L\&S) & $\mathrm{g}$ & $2.0 \mathrm{E}+05$ & $7.7 \mathrm{E}+11$ & $1.6 \mathrm{E}+17$ & {$[14]$} \\
\hline 34 & Animal Fat (without L\&S) & $\mathrm{g}$ & $2.0 \mathrm{E}+05$ & $4.7 \mathrm{E}+11$ & $9.5 \mathrm{E}+16$ & [14] \\
\hline 35 & Animal Meal (with L\&S) & $\mathrm{g}$ & $5.0 \mathrm{E}+05$ & $3.1 \mathrm{E}+11$ & $1.6 \mathrm{E}+17$ & {$[14]$} \\
\hline 36 & Animal Meal (without L\&S) & $\mathrm{g}$ & $5.0 \mathrm{E}+05$ & $1.9 \mathrm{E}+11$ & $9.5 \mathrm{E}+16$ & [14] \\
\hline
\end{tabular}

References for UEVs:

[1] Brown and Ulgiati, 2016; [2] After Odum, 1996; [3] Assumed from economical allocation; [4] After Brown et al., 2011; [5] After Brown and Ulgiati, 2004b; [6] After Bargigli, 2004; [7] After Bargigli and Ulgiati, 2003; [8] After Cohen et al., 2007; [9] After Ganeshan et al., 2005; [10] After Mellino et al., 2013; [11] After Buranakarn, 1998; [12] After Björklund et al., 2001; [13] After Pereira et al., 2013; [14] This Work; [15] After Ghisellini et al., 2015b 


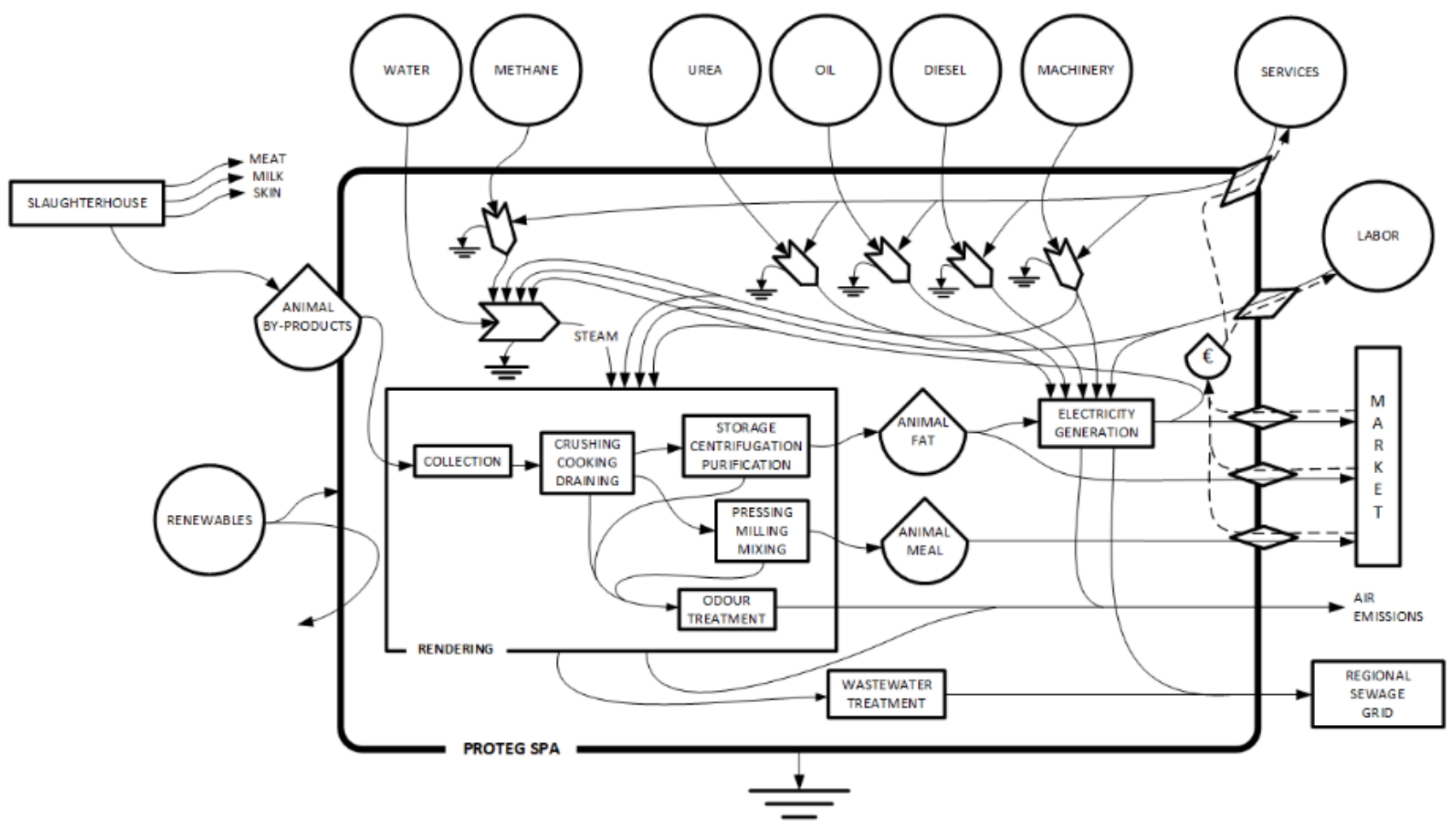

Figure B.2 - System diagram of Case 3 (where the by-products flow is assigned a fraction of the total exergy of the slaughterhouse output flows (milk, meat, skin, by-products)).

Table B.2 - Electricity from animal by-products (CASE 3)

\begin{tabular}{|c|c|c|c|c|c|c|}
\hline$\#$ & Item & Unit & Inputs & $\begin{array}{c}\text { UEV } \\
\text { (sej/unit) }\end{array}$ & $\begin{array}{c}\text { Emergy } \\
\text { (sej/MWh) }\end{array}$ & Ref. \\
\hline \multicolumn{7}{|c|}{ R - Renewable Inputs Locally Available } \\
\hline 1 & Sun & $\mathbf{J}$ & $1.4 \mathrm{E}+08$ & $1.0 \mathrm{E}+00$ & $1.4 \mathrm{E}+08$ & Def. \\
\hline \multirow[t]{2}{*}{2} & Deep Heat & $\mathrm{J}$ & $3.9 \mathrm{E}+05$ & $4.9 \mathrm{E}+03$ & $1.9 \mathrm{E}+09$ & {$[1]$} \\
\hline & \multicolumn{6}{|c|}{ Secondary and tertiary renewable sources } \\
\hline 3 & Rain & $\mathrm{J}$ & $1.2 \mathrm{E}+06$ & $7.0 \mathrm{E}+03$ & $8.7 \mathrm{E}+09$ & {$[1]$} \\
\hline 4 & Wind & $\mathrm{J}$ & $4.0 \mathrm{E}+06$ & $8.0 \mathrm{E}+02$ & $3.2 \mathrm{E}+09$ & {$[1]$} \\
\hline \multicolumn{7}{|c|}{ N-Non-renewable Inputs Locally Available } \\
\hline 5 & Underground water & $\mathrm{J}$ & $5.7 \mathrm{E}+06$ & $2.3 \mathrm{E}+06$ & $1.3 \mathrm{E}+13$ & {$[2]$} \\
\hline \multicolumn{7}{|c|}{ F - Non-renewable Imported Inputs } \\
\hline 6 & Cat. 3 Material (d.m.) - w/o L\&S & $\mathrm{g}$ & $7.0 \mathrm{E}+05$ & $8.6 \mathrm{E}+09$ & $6.1 \mathrm{E}+15$ & [14] \\
\hline 7 & Cat. 3 Material (d.m.) - w L\&S & $\mathrm{g}$ & $7.0 \mathrm{E}+05$ & $1.4 \mathrm{E}+10$ & $9.9 \mathrm{E}+15$ & [14] \\
\hline 8 & Natural Gas & $\mathrm{J}$ & $4.2 \mathrm{E}+09$ & $1.4 \mathrm{E}+05$ & $5.9 \mathrm{E}+14$ & {$[4]$} \\
\hline 9 & Diesel for transportation & $\mathrm{J}$ & $7.1 \mathrm{E}+08$ & $1.4 \mathrm{E}+05$ & $1.0 \mathrm{E}+14$ & {$[4]$} \\
\hline 10 & Diesel for engine & $\mathrm{J}$ & $1.3 \mathrm{E}+07$ & $1.4 \mathrm{E}+05$ & $1.8 \mathrm{E}+12$ & {$[4]$} \\
\hline 11 & Lubricating oil & $\mathrm{J}$ & $9.0 \mathrm{E}+06$ & $1.1 \mathrm{E}+05$ & $1.0 \mathrm{E}+12$ & {$[4]$} \\
\hline \multirow[t]{2}{*}{12} & Urea & g & $2.4 \mathrm{E}+04$ & $4.8 \mathrm{E}+09$ & $1.1 \mathrm{E}+14$ & {$[5]$} \\
\hline & Machinery & & & & & \\
\hline 13 & Steel & $\mathrm{g}$ & $1.1 \mathrm{E}+03$ & $2.7 \mathrm{E}+09$ & $3.0 \mathrm{E}+12$ & {$[6]$} \\
\hline 14 & Aluminum & $\mathrm{g}$ & $2.6 \mathrm{E}+01$ & $4.1 \mathrm{E}+07$ & $1.1 \mathrm{E}+09$ & [6] \\
\hline 15 & Plastics \& Rubbers & $\mathrm{g}$ & $1.1 \mathrm{E}+02$ & $2.4 \mathrm{E}+09$ & $2.7 \mathrm{E}+11$ & {$[5]$} \\
\hline 16 & Copper & $\mathrm{g}$ & $6.8 \mathrm{E}+00$ & $5.8 \mathrm{E}+08$ & $3.9 \mathrm{E}+09$ & {$[6]$} \\
\hline 17 & Cast Iron & $\mathrm{g}$ & $1.4 \mathrm{E}+02$ & $1.9 \mathrm{E}+09$ & $2.7 \mathrm{E}+11$ & [7] \\
\hline 18 & Lead & $\mathrm{g}$ & 2.7E-01 & $3.6 \mathrm{E}+11$ & $9.9 \mathrm{E}+10$ & {$[8]$} \\
\hline
\end{tabular}




\begin{tabular}{|c|c|c|c|c|c|c|}
\hline 19 & Iron & $\mathrm{g}$ & $7.1 \mathrm{E}+00$ & $2.7 \mathrm{E}+09$ & $1.9 \mathrm{E}+10$ & {$[6]$} \\
\hline 20 & Glass & $\mathrm{g}$ & $2.1 \mathrm{E}-01$ & $2.5 \mathrm{E}+09$ & $5.2 \mathrm{E}+08$ & [5] \\
\hline 21 & Polypropylene & $\mathrm{g}$ & $3.7 \mathrm{E}+00$ & $2.4 \mathrm{E}+09$ & $8.9 \mathrm{E}+09$ & {$[5]$} \\
\hline 22 & Silicon Carbide & $\mathrm{g}$ & $1.5 \mathrm{E}+01$ & $2.3 \mathrm{E}+09$ & $3.4 \mathrm{E}+10$ & [9] \\
\hline 23 & Polyethylene & g & $2.5 \mathrm{E}+01$ & $2.4 \mathrm{E}+09$ & $6.1 \mathrm{E}+10$ & [5] \\
\hline 24 & Concrete & $\mathrm{g}$ & $4.3 \mathrm{E}+03$ & $1.3 \mathrm{E}+09$ & $5.4 \mathrm{E}+12$ & [10] \\
\hline 25 & Limestone & $\mathrm{kg}$ & 3.9E-02 & $2.1 \mathrm{E}+12$ & $8.3 E+10$ & [2] \\
\hline 26 & Fiber Glass & $\mathrm{g}$ & $3.5 \mathrm{E}+00$ & $7.4 \mathrm{E}+09$ & $2.6 \mathrm{E}+10$ & [11] \\
\hline 27 & Rock Woll & $\mathrm{g}$ & $1.6 \mathrm{E}+00$ & $2.3 \mathrm{E}+09$ & $3.7 \mathrm{E}+09$ & [12] \\
\hline 28 & Bitumen & $\mathrm{J}$ & $3.5 \mathrm{E}+04$ & $1.4 \mathrm{E}+05$ & $4.8 \mathrm{E}+09$ & {$[4]$} \\
\hline \multicolumn{7}{|c|}{ L\&S - Information and Infrastructure } \\
\hline 29 & Labour & $\mathrm{ppl} / \mathrm{yr}$ & $1.4 \mathrm{E}-03$ & $4.4 \mathrm{E}+16$ & $6.0 \mathrm{E}+13$ & [13] \\
\hline 30 & Services & $€$ & $7.4 \mathrm{E}+01$ & $1.7 \mathrm{E}+12$ & $1.2 \mathrm{E}+14$ & [13] \\
\hline \multicolumn{7}{|c|}{ Output } \\
\hline \multirow[t]{2}{*}{31} & Electricity (with L\&S) & MWh & 8.6E-01 & $1.3 \mathrm{E}+16$ & $1.1 \mathrm{E}+16$ & [14] \\
\hline & & $\mathrm{J}$ & $3.1 \mathrm{E}+09$ & $3.5 \mathrm{E}+06$ & $1.1 \mathrm{E}+16$ & [14] \\
\hline \multirow[t]{2}{*}{32} & Electricity (without L\&S) & MWh & 8.6E-01 & $8.0 \mathrm{E}+15$ & $6.9 \mathrm{E}+15$ & [14] \\
\hline & & $\mathbf{J}$ & $3.1 \mathrm{E}+09$ & $2.2 \mathrm{E}+06$ & $6.9 \mathrm{E}+15$ & [14] \\
\hline 33 & Animal Fat (with L\&S) & $\mathrm{g}$ & $2.0 \mathrm{E}+05$ & $5.5 \mathrm{E}+10$ & $1.1 \mathrm{E}+16$ & [14] \\
\hline 34 & Animal Fat (without L\&S) & $\mathrm{g}$ & $2.0 \mathrm{E}+05$ & $3.4 \mathrm{E}+10$ & $6.9 \mathrm{E}+15$ & [14] \\
\hline 35 & Animal Meal (with L\&S) & $\mathrm{g}$ & $5.0 \mathrm{E}+05$ & $2.2 \mathrm{E}+10$ & $1.1 \mathrm{E}+16$ & [14] \\
\hline 36 & Animal Meal (without L\&S) & $\mathrm{g}$ & $5.0 \mathrm{E}+05$ & $1.4 \mathrm{E}+10$ & $6.9 \mathrm{E}+15$ & [14] \\
\hline
\end{tabular}

References for UEVs:

[1] Brown and Ulgiati, 2016; [2] After Odum, 1996; [3] Assumed from economical allocation; [4] After Brown et al., 2011; [5] After Brown and Ulgiati, 2004b; [6] After Bargigli, 2004; [7] After Bargigli and Ulgiati, 2003; [8] After Cohen et al., 2007; [9] After Ganeshan et al., 2005; [10] After Mellino et al., 2013; [11] After Buranakarn, 1998; [12] After Björklund et al., 2001; [13] After Pereira et al., 2013; [14] This Work. 